\title{
DISKURSUS KEILMUAN: SEJARAH TRANSMISI FILSAFAT HELLENISME DALAM FILSAFAT ISLAM
}

Oleh: Ali M. Hassasn Palawa*

\author{
Hikmah adalah barang hilangnya \\ kaum beriman, maka siapa saja menemukannya \\ Hendaklah ia memungutnya \\ [Hadis Nabi]
}

\section{A. Pendahuluan}

Dalam diskursus keilmuan antara Hellenisme dan Islam telah terjadi proses timbal balik, yaitu terjadinya Hellenisasi Islam dan Islamisasi Hellenis. Kalau dijabarkan akan mengandung makna bahwa kata "Hellenis" merefresentasikan ilmu [filsafat] yang secara epistimologis perolehannya lewat akal (ratio). Sementara kata "Islam" mencerminkan ajaran-ajaran yang mencapiannya melalui wahyu (revalation). Lebih lanjut, "Hellenisasi Islam" merupakan upaya-upaya untuk mentransfer nilai-nilai kebanaran (hasil olah akal) ke dalam Islam. Sebaliknya, "Islamisasi Hellenis" [persisnya Islamisasi ilmu $^{2}$ ] adalah usaha-usaha untuk menuangkan ajaran-ajaran kebenaran Islam

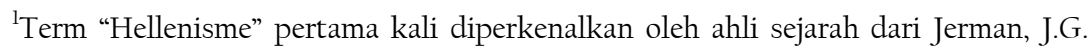
Droysen. Ia menggunakan perkataan "hellenismus" sebagai sebutan untuk masa yang dianggapnya sebagai periode peralihan antara Yunani kuna dan dunia Kristen. Droysen sepertinya lupa akan peranan Roma dalam agama Kristen (dan membatasi seolah-olah hanya Yunani saja yang berperan). Namun, ia diakui telah berhasil mengidentifikasi suatu kenyataan sejarah yang amat penting. Biasanya zaman Hellenik yang disebut-sebut sebagai peralihan itu adalah masa sejak tahun 323 sampai 30 S.M. atau dari kematian Iskandar Agung sampai penggabungan Mesir (setelah ditakluknya Kaleopatra) ke dalam kekaisaran Romawi. Sebab dalam periode itu muncul banyak kerajaan di sekitar Laut Tengah, khususnya di pasisir timur dan selatan, seperti Syiria dan Mesir yang diperintah oleh bangsa Mecedonia dari Yunani. Akibatnya, mereka ini membawa berbagai perubahan besar dalam banyak bidang di kawasan itu, antara lain bahasa (daerah-daerah itu didominasi oleh bahasa Yunani) dan pemikirannya (ilmu pengetahuan, terutama filsafat), diserap oleh daerah-daerah itu melalui berbagai cara. Lihat, Encyclopaedia Britanica, "Hellenic Age", Vol. 11, (Chicago: William Benton, 1970), hal. 323; bandingkan, Paul Edwards (ed.), The Encyclopedia of Philosophy, Vol. 3 \& 4 (New York: Macmillan Publishing, 1972), hal. 467. Umumnya batasan (rentang waktu) Hellenisme seperti paparkan di atas, pendekatannya lebih pada sudut pandang sejarah politik. Namun, kalau pendekatannya dari sudut pandang sejarah budaya maka rentang waktunya bisa surut ke belakang hingga sampai pada pengaruh pemikiran dan budaya Yunani kuna (sekitar mulai abad IV atau III SM.); dan sekaligus maju ke depan sampai ketika ditaklukannya daratan Madetarnean oleh bangsa dan budaya Arab dan Islam (sekitar abad VII M.). Lihat, S.D. Goitein, Studies in Islam History and Institutions (Leiden: E.J. Brill, 1968), 56.

${ }^{2}$ Kalau Islamisasi ilmu adalah respon Islam terhadap filsafat-spekulatif, boleh jadi merupakan lahan yang subur karena cukup banyak tradisi Hellenisme yang perlu "dijinakkan" oleh ajaran Islam. Namun, kalau tujuannya adalah islamisasi sains-empiris, sepertinya domain
} 
(hasil arahan wahyu) ke dalam Hellenisme. Sehingga kemungkinan implikasinya ada tiga: (i) bahwa telah terjadi Hellenisasi dalam doktrindoktrin pemahaman agama Islam; atau sebaliknya (ii) bahwa justru Islam telah "mengislamkan" nilai-nilai kebenaran Hellenisme; atau malah ada kemungkian lain, (iii) bahwa keduanya sudah saling bercambur dan mengalami konfergensi satu dengan lainnya.

Gelombang hellenisme yang melanda dunia Islam merupakan akibat wajar dari kegiatan penerjemahan karya-karya Yunani ke dalam bahasa Arab. Lebih jauh, hasil logis dari penerjemahan itu melahirkan suasana kondusif dan kegairahan yang subur di kalangan umat Islam tertentu guna mengembangkan pemikiran spekulatif. Gelombang hellenisme tersebut merupakan suatu pengalaman yang, menurut Nurcholish Madjid, "tercampur antara mamfaat dan mud\}arat bagi umat Muslimin". ${ }^{3}$ Akibat dari itu membuat mereka terbagi antara yangmenyambut (respon-positif) dan menolak (respon-negatif). Respon umat Islam atas hellenisme dapat menjadi ukuran kreativitas mereka dalam menghadapi suatu bentuk tantangan zaman. Lebih jauh Nurcholish Madjid memaparkan:

Sebagian besar Ummat, khususnya mereka yang ada di bawahnaungan ideologi Jama'ah dan Sunnah, semula cukupenggan, kalau tidak memusuhi, Hellenisme itu. Tapi secara umum terhadap banyak kaum Muslimin yang mempelajari pikiran-pikiran asing itu dengan tekun, disertai kematapan beragama dan kepercayaan diri kepada diri sendiri secukupnya. Mereka ini, dengan kebebesan berfikir yang masih leih besar lagi daripada kaum Mu'tazilah, mengembangkan filsafat itu dan memberi watak keislaman kepadanya. Maka lahirlah suatu disipli ili dalam khazanah intelektual Islam yang secara tekhnis disebut alfalasafah. Dari kalangan mereka ini timbul kelompok baru kaum tepelajar Muslim, yaitu al-falasifah (kaum Failusuf), suatu penamaan khusus kepada kaum intelektual Muslim yang sengat terpengaruh oleh filsafat Yunani. ${ }^{4}$

Dalam merespon positif pemikiran hellenisme itu, filosuf Muslim terbagi dalam dua aliran yang besar, yang keduanya mengklaim dirinya sebagai pengikut filsafat Yunani. Pertama, aliran Peripatetik (Mashsha'iyyah) [disebut demikian karena kalau Aristotels mengajar ia berjalan-jalan di

yang "kering" karena sains-empiris itu sendiri adalah bebasa nilai. Bukan itu saja, sejak pertama pada 1982 digagas oleh Raji' Ismai'il al-Faruqi, Islamisasi ilmu telah menjadi wacana pro dan kontra yang telah menyita perhatian dan energi sebagian kalangan serjana Muslim, dan mengakibatkan, menurut Azra, kurangnya perhatian diberikan kepada masalah-masalah yang tidak kalah esesnsinya, justru memerlukan pemecahan-pemecahan kongrit dan mendesak. Lihat, Azyumardi Azra, Pendidikan Islam Tradisi dan Modernisasi Menuju Melinium Baru (Jakarata: Logos, 1999), 15-16.

${ }^{3}$ Nurcholish Madjid, Khazanah Intelektual Islam (Jakarta: Bulan Bintang, 1984), 25

${ }^{4}$ Nurcholish Madjid, (ed.) Khazanah Intelektual Islam, 25. 


\section{Diskursus Keillmuan: 3 \\ Sejarah Transmisi Filsafat Hellenisme dalam Filsafat Islam}

tengah-tengah siswanya] yang memiliki ajaran gabungan ide-ide dari Aristoteles dan (sebagian) ide Neo-Platonik. ${ }^{5}$ Ide yang terpenting yang diambil dari Aristoteles adalah doktrin tentang Akal (Nous), wujud yang lebih tinggi dari semua realitas jiwa yang ada. Akal adalah penaggerak pertama yang tidak bergerak; dan akan yang bersifat immortal (tidak mati). Akal adalah supreme deity (Tuhan Maha Tinggi) yang selalu berpikir dan merunungkan diri-Nya. Sementara itu, ide yang diambil dari Neo-Platonisme adalah doktrin yang mengajarkan tentang the One (yang Tunggal) sebagai prinsip tertinggi atau sumber penyebab. Aliran ini juga dikenal sebagai cerminan upaya terbaik pemikiran manusia untuk mencapai kebenran. Aliran ini biasanya berawal dari filosuf Islam al-Kindi dan mencapai puncaknya pada diri filosuf Islam Andalusia, Ibn Rusyd. ${ }^{6}$

Kedua, aliran Illuminasi (Isyraqiyah) [disebut demikian karena merupakan kearifan spritual yang muncul dari timur] yang lebih bersimpati kepada gabungan ajaran dan tradisi Pytagoras-Platonik. Ajaran dualis Plato kemudian diusahakan penyatuannya oleh para penganut Neo-Pytagoras. ${ }^{7}$ Ajaaran ini menyatkan mereka menuruti doktrin bukan saja dri golangan Pytaagoras, tetapi bahkan juga dari nabi-nabi kuno, khususnya Nabi Sulaiman dan Idris (tradisi Hermetis) dan juga dari ajaran-ajaran bijak, seperti Zoroaster. Dalam Islam alaiaran ini berawal dari Ibn Sina dan mencapai puncaknya pada diri Suhrawardi al-Maqtul. Dengan demikian, aliran ini dipandang sebagai ajaran yang lebih berdasrkan pada ilmu ilahah tinimbang pada ilmu insaniyah. ${ }^{8}$

B. Wacana Keilmuan: Univikasi Akal-Filsafat dan Wahyu-Agama

Dikotomi antara akal dan wahyu sebagai sumber pengetahuan dan petunjuk kebenaran; ${ }^{9}$ dan disparitas antara ilmu-ilmu Hellenisme dan ilmu-

${ }^{5}$ Seyyed Hossein Nasr, Science and Civilization in Islam,

${ }^{6}$ Seyyed Hossein Nasr, Science and Civilization in Islam,

${ }^{7}$ Seyyed Hossein Nasr, Science and Civilization in Islam,

${ }^{8}$ Seyyed Hossein Nasr, Science and Civilization in Islam,

${ }^{9}$ Dipahami bahwa sumber pengetahuan dan petunjuk kebenaran yang disebut pertama bersifat relatif (tidak pasti) dan tidak mutlak benar; sedangkan yang disebut belakangan bersifat absolut (pasti) dan mutlak benar. Timbul pertanayaan, kenapa kemudian muara kedua sumber tadi terjadi klaim yang berbeda: akal relatif dan wahyu (tetap) absolut? Seharusnya klaimnya tetap sama, karena bukankah keduanya sama-sama dari Tuhan. Untuk memecahakan masalah ini, jawaban sederhana dan sering diajukan bahwa akal adalah hasil olah pikir manusia yang nisbi, dan sangat mungkin untuk tidak "terjamin" sebab kebenaranya sudah terkontaminasi dengan sifat kemanusiawian manusia. Artinya, anugrah akal sebagai sumber kebenaran dan pengetahuan sudah tidak dapat terjamin secara absolut. Pertanyaan kejaran berikurnya, bagaimana kalau akal dapat terjamin? Sebutlah misalnya pada orang-orang khawas, meminjam istilah kategorisasi manusia yang dilakukan oleh al-Ghazali. Kalau ini dapat dibenarkan, pada gilirannya berarti bahwa kebenaran diperoleh akal juga absolut. Dengan perspektif seperti ini, tidaklah aneh kalau Muahmmad Abduh memberikan kedudukan dan peran akal yang sangat tinggi, bahkan rasionalitasnya melebihi Mu'tazilah. Lebih lanjut, lihat 
ilmu Islam begitu nyata dan kental di awal sejarah pembentukan ajaran agama Islam. Sedemikian nyata dan kentalnya sehingga upaya-upaya relevansi dan univikasi serta harmonisasi antara akal (filsafat) dan wahyu (agama), menurut Harun Nasution, ${ }^{10}$ telah menjadi polemik dan perdebatan yang akut serta berkepanjangan dalam sejarah tradisi pemikiran dan intelektual di kalangan ulama-ulama (sarjana-sarjana) Muslim, terutama di kalangan sarjana teolog Mulsim, khusus dari aliran Mu'tazilah dan Asy'ariah. Begitu pula polemik dan perdebatan tersebut telah pula terjadi di kalangan para Filosuf Muslim, misalnya di awali oleh al-Kindi, dilanjutkan oleh alFarabi dan disempurnakan oleh Ibn Sina serta filosuf sesudah mereka, khususnya Ibn Rusyd. ${ }^{\text {II }}$

Di kalangan para filosuf Muslim masalah univikasi antara akal dan wahyu telah menyita perhatian mereka yang paling awal untuk diselesaikan dengan segera sebelum memasuki persoalan-persoalan filosofis lainnya. ${ }^{12}$ Beberapa nama filosuf yang berusaha untuk mencari relevansi dan mengupayakan univikasi antara akal dan wahyu sebagai refresentasi dari filsafat dan agama secara umum adalah filosuf al-Kindi. ${ }^{13}$ Kemudian upaya alKindi ini diteruskan dan disempurnkan oleh al-Farabi. Lewat teori emanasinya, ia mengidentifikasi akal aktif (Active Intellect - al-'Aql al-Fa'a l) sebagai akal yang tertinggi dalam hirarki teori emanisnya. Karenanya, akal aktif juga disamakan dengan akal kesepuluh. Dan bahkan lebih lanjut disebut-sebut bahwa akal kesepuluh identik atau setidak-tidaknya dapat berhubungan dangan malaikat Jibril. Kalau begini halnya, karena kebenaran yang diperoleh Nabi dengan wahyu lewat malaikat Jibril, dan kebenaran yang diterima oleh filosuf dengan akal yang memampu berhubungan dan malaikant Jibril, maka tidak ada pertentangan antara akal dan wahyu dalam Islam. ${ }^{14}$ Begitu juga dengan Ibn Tufail, lewat karyanya yang sangat ilustratif, Hayy bin Yaqzan, ${ }^{15}$ suatu karya novel ellagoris yang menganalogikan akal dengan Hayy bin Yaqzan dan wahyu dengan analogi seorang ulama yang bernama Asal yang masing-masing hidup di pulau terpencil. ${ }^{16}$

Muhammad Abduh, Risalah al-Tauhid, (Kairo: t.p., 1366), hal. 127; lihat juga, Harun Nasution, Muhammad Abduh dan Teologi Rasionalitas Mu'tazilah (Jakarta: UI-Press, 1987), 34

${ }^{10}$ Harun Nasution, Akal dan Wahyu Dalam Islam (Jakarta: UI-Press, 1986), 5.

${ }^{11}$ Hitti, Philip K., History of the Arab (London: Macmillan Press, 1970), 371

${ }^{12}$ Lebih lanjut lihat, Ibrahim Madhkur, Filsafat Islam: Metode dan Penerapan (Jakarta: Rajawali Press, 1993), 8.

${ }^{13}$ Lebih lanjut, misalnya lihat, Goerge N. Atiyeh, al-Kindi: Tokoh Filosuf Muslim (Bandung: Pustaka, 1983), 17.

${ }^{14}$ Misalnya lihat, Ian Richard Netton, al-Farabi and His School ( London-New York: Routledge, 1992), 49.

${ }^{15}$ Lihat, Nurcholish Madjid, "Pengantar" dalam Nilai-nilai Dasar Perjuangan (NDP) Himpunan Mahasiswa Islam (HMI), (Jakarta: PB HMI, 2008).

${ }^{16}$ (Menurut Sulaiman Dunia, editor karya-karya Ibn Tufayl, pulau-pulau yang dimaksud kemungkinan pulau-pulau di Nusantara [Indonesia]). Lihat, misalnya, Harun 


\section{Diskursus Keillmuan: | \\ Sejarah Transmisi Filsafat Hellenisme dalam Filsafat Islam}

Selanjutnya, Ibn Rushd, juga mengarang suatu risalah untuk menyelaraskan antara akal wahyu (filsafat dan syari'ah). ${ }^{17}$ Bahkan, sesungguhnya polemik kalam yang ortodoks (oreintas wahyu lahiriyah) dan filsafat liberal (oreintasi akal ellagoris) yang diwakili oleh polemik posthumous antara al-Ghazali (Tahasfut al-Falassifah) dan Ibn Rushd (Tahasfut al-Tahasfut) dapat dikatakan masih dalam koridor akal dan wahyu. ${ }^{18}$ Suatu pengecualian, seorang filosuf Muslim, al-Razi tidak mempercayai wahyu dan kenabian. Menurut filosuf ini, akal sudah cukup mamadai untuk mengatahui dan membedakan baik dan buruk. Baginya karya-karaya ilmiah lebih berguna dan bernilai tinggi dibandingkan dengan Kitab Suci. Gagasan seperti ini sangat berani karena mencedarai ajaran pokok agama. Al-Razi memang seorang filosuf yang sangat rasional dan liberal. Tiada pemikir Muslim sepanjang sejarah tradisi pemikiran dan intelektual Islam serasional dan seliberal dia. Tetapi persoalannya, apakah ini benar-benar merupakan pendapat murni darinya; jangan-jangan itu tidak lebih adalah tuduhan lawan polemiknya. ${ }^{19}$

Begitu pula, disparitas antara ilmu-ilmu Hellenisme dan ilmu-ilmu Islam pada akhirnya memberi implikasi pada sistem kependidikan dalam Islam. Sekedar contoh, al-Ghazali misalnya, mengklasifikasikan ilmu kepada "ilmu agama" dan 'ilmu non-agama." Diantara kedua jenis ilmu ini, menurut al-Ghazali, yang wajib dituntut adalah jenis ilmu yang pertama. ${ }^{20}$ Senada dengan itu, meskipun Naquib al-Attas mengakui bahwa semua ilmu

Nasution, Akal dan Wahyu, 55; Abdul Halim Mahmud, Falsafah Ibn Tufail wa Risalah Hayy bin Yaqzan (Bairut: Dar al-Kitab al-Banani, 1982), 50 dan 73; Majid Fahry, A History of Islamic Philosophy (New York: Colombia, 1970), 295; M.M. Syarif, Para Filosuf Muslim (Bandung: Mizan, 1994), 47; Ahmad Fuad al-Ahwani, Filsafat Islam (Jakarta: Pustaka Firdaus, 1995), 104.

${ }^{17}$ Lihat, Ibn Rushd, Fas\}l al-Maqa>l Fi $>$ ma> Bayn al-Hikam wa al-Syariah min Ittis\}al (Cairo: Dar al-Ma'arif, 1972), 31; bandingka dengan Nurcholish Madjid, (ed.), Khazanah Intelektual Islam, (Jakarta: Bulan Bintang, 1984), hal. 215.

${ }^{18}$ Lihat, Nurcholis Majid, Islam doktrin dan Peradaban (Jakarta: Paramadina, 1992), 280; lihat juga, Iysa A. Bello, The Medieval Islamic Controversy Between Philosophy and Orthodoxy: Ijma' and Ta'wil in The Conflict Between al-Ghazali and Ibn Rushd (Leiden: E.J. Brill, 1989), 69.

${ }^{19}$ Lihat, Harun Nasution, Filsafat dan Mistisisme dalam Islam (Jakarta: Bulan Bintang, 1992), 23; lihat juga, M.M. Syarif, A History of Muslim Philosophy, 47.

${ }^{20}$ Masalah ilmu-ilmu yang diajarakan dalam Islam merupakan hal yang mendasar sejak Islam klasik: apakah ada bentuk ilmu khusus harus dicari (dipelajari)? Sebagaian besar ulama Islam hanya memasukkan cabang-cabang ilmu yang secara langsung berhubungan dengan agama. Sedangkan tipe-tipe ilmu lainnya, mereka menyerahkan kepada masyarakat untuk menentukan ilmu mana paling esensial untuk dapat memelihara dan menyejehterakan hidup mereka. Al-Ghazali sendiri, misalnya, lebih memandang bahwa ilmu yang wajib dicari, menurut tuntunan agama adalah terbatas pada pelaksanaan kewajiban-kewajiban Syariah Islam yang harus diketahui dengan pasti. Lebih lanjut al-Ghazali membagi ilmu kepada "ilmu agama" dan "ilmu non-agama."Yang ia maksud dengan "ilmu agama" ('ulusm syar'i) adalah ilmu yang diajarakan lewat ajaran-ajaran Nabi dan wahyu; sedangkan di luar ilmu termasuk "ilmu non-agama". Selanjutnya "ilmu non-agama" itu sendiri diklasifikasikan kepada yang terpuji (mah\}mud), dibolehkan (mu>bah) dan tercela (maz\}mum). Lihat Mahdi Ghulsyani, Filsafat Sains menurut Al-Qur'an (Bandung: Mizan, 1988), 40-41. 
datangnya dari Allah, tetapi ia tetap saja mengkalasifikasi ilmu "berian Allah" dan ilmu "capaian manusia," berturut-turut bersifat wajib atas semua Muslim (fard\}u 'ayn) dan wajib bagi sebagian Muslim (fard\}u kifaryah) dalam menuntutnya. Lebih dalam Naquib al-Attas menyatakan:

.... sebagaimana manusia memiliki dwi-sifat, demikian pulalah ilmu terdiri atas dua jenis: yang pertama adalah ilmu berian Allah, dan yang kedua adalah ilmu capaian (yang diperoleh dengan usaha). Pada hakekatnya, dalam Islam, semua ilmu datangnya dari Allah, tetapi cara kedatangannya -yaitu hushul dan wushul- serta fakultas-fakultas dan indera-indera yang menerima dan menafsirkannya berbeda. Mengingat ilmu jenis pertama adalah mutlak penting bagi pembimbingan dan penyelamatan manusia, maka ilmu tentangnya -tercakup dalam ilmiilmu agama-- bersifat perlu dan wajib atas semua Muslim (fardhu 'ayn). Pencapain jenis ilmu kedua --mencakup ilmu-ilmu rasional, intelektual, dan filosofis-- wajib bagi sebagian Muslim saja (fardhu kifayah). ${ }^{21}$

Kalau ditilik lebih jauh, sesungguhnya dikotomi akal dan wahyu serta implikasinya pada disparitas antara ilmu-ilmu Hellenisme (pencapaian lewat akal) dan ilmu-ilmu Islam (peroleh melalui wahyu) pada tataran realitas tidak perlu terjadi. Mengingat adanya argumentasi pada dataran idealitas: pertama, kedua sumber tersebut sama-sama berasal dan "diciptakan" dari Wujud Tunggal. Atau paling tidak, meskipun dapat dibedakan tetapi tidak dapat dipertentangkan satu dengan lainnya, sebagaimana ungkapan Mullah Muhsin Faydh Kasyani, "akal adalah syariah yang diwahyukan dalam diri manusia; syariah yang diwahyukan itu adalah akal di luar diri manusia ... Pendeknya, sumber dari semua sifat baik dan asal-usul dari semua kesempurnaan adalah akal."22 Sehingga pada gilirannya, suatu keniscayaan, kalau akal dan wahyu tidak terdapat kontradiksi di dalamnya; dan adalah absurd serta tidak intellegible kalau ditemukan pertentangan antara keduanya. Keniscayaan ini tidak saja berdasarkan argumen aqli tetapi juga dilandaskan pada peneguhan naqli.

Kedua, bahwa tradisi pemikiran dan intelektual serta peradaban anak manusia pada awalnya berakar pada akal dan wahyu (dalam pengertian tunggal) yang berasal dari tradisi nubuwwah atau wahyu ilahiyyah, seperti ungkapan Arab yang masyhur, "yanba'u al-hikmah min misykast al-nubuwwah"

${ }^{21}$ Lihat, Naquib al-Attas, Konsep Pendidikan dalam Islam (Bandung: Mizan, 1984), 86. Mengenai konsep pendidikan al-Attas tentang kategorisasi ilmu-ilmu agama (fard\}u ayn) dan ilmu-ilmu sains (fard\}u kifa>yah) serta pemikiran-pemikiran pendidikannya secara komprehensif dengan uraian yang sangat baik dan otoritatif, lihat Wan Mohd Nor Wan Daud, Filsafat dan Praktik Pendidikan Islam Syed M. Naquib Al-Attas (Bandung: Mizan, 2003), 274-290.

${ }^{22}$ Lebih lanjut uraian tentang akal dalam perspektif filosofis dan sufistik, lihat, Sociko Murata, The Tao of Islam (Bandung: Mizan, 1996), 310. 


\section{Diskursus Keillmuan: 7 \\ Sejarah Transmisi Filsafat Hellenisme dalam Filsafat Islam}

(sumber-sumber hikmah berasal dari relung kenabian). ${ }^{23}$ Tradisi ilmu dan filsafat Yunani kalau ditelusuri berasal Harmes Trismegistus, oleh banyak kalangan diidentifikasi sebagai Nabi Idris (Enoch dalam Perjanjian Lama), pendiri sains dan filsafat serta peradaban, ${ }^{24}$ bahkan dia disebut sebagai Abu alHukama' (Bapak Para filosuf). ${ }^{25}$ Begitu pula misalnya, betapa filosuf-filosuf Yunani kuno belajar ilmu pengetahuan dan filsafat dari orang-orang disebut "h\}ukama>" (bijak), sebagaimana disingung dalam al-Qur'an, seperti Lukman al-Hakim; atau mereka belajar dan mendapat pengajaran ilahiah dari sahabatsahabat terdekat para nabi, seperti Nabi Daud dan Sulaiman, ${ }^{26}$ sekedar menyebut beberapa nama.

Ketiga, sementara itu, diberbagai kawasan, seperti Mesir, Persia, India dan Cina terdapat "orang-orang bijak" dan "guru-guru kebenaran" yang, boleh jadi, mendapat "berita" (Arab: naba') dari Tuhan guna membimbing masyarakatnya kepada kebaikan (nilai etis), kebenaran (nilai logis) dan keindahan (nilai estetis) dalam kehidupan di dunia. Al-Qur'an sendiri mengisyaratkan dengan gamblang bahwa rasul itu jumlahnya banyak sekali; dan Nabi saw. sendiri dalam sebuah hadis menyebutkan jumlah mereka sebanyak 315 orang. ${ }^{27}$ Mengingat jumlah mereka begitu bayak maka tidak seluruhnya diceritakan dalam al-Qur'an. ${ }^{28}$

Namun, secara umum al-Qur'an menyebutkan bahwa Allah membangkitkan seorang rasul untuk setiap ummat, ${ }^{29}$ dan bahwa setiap kaum mempunyai penunjuk jalan, ${ }^{30}$ dan bahwa tidak satu ummatpun kecuali pernah tampil kepadanya seorang pemberi peringat. ${ }^{31}$ Karenya, tidak tertutup kemungkinan kalau orang seperti Aleksander Agung (Mesir), Zoroaster (Persia), Sidharta Gautama (India) serta Lao Tse dan Confusius (Cina) atau beberapa tempat yang mampu menjadi "guru bangsa" juga salah seorang di antara 315 orang rasul, seperti sabda Nabi saw. ${ }^{32}$ Kalau nabi tentu lebih

${ }^{23}$ Lihat, Seyyed Hossein Nasr, "The Qur'an and Hadith as Source and Inspiration of Islamic Philosophy”, dalam Seyyed Hossein \& Oliver Leaman, History of Islamic Philosophy (London \& New York: Routledge, 1996), 30.

${ }^{24}$ Seyyed Hossein Nasr, Science and Civilization in Islam (Cambrige: Harvard University Press, 1968), 31; lihat juga, Louis Marlow, Masyarakat Egaliter Visi Islam (Bandung: Mizan, 1997), $57-58$.

${ }^{25}$ Seyyed Hossein Nasr, "The Qur'an and Hadith....", 30.

${ }^{26}$ Lihat, T.J. De Boer, The History of Philosophy in Islam (New York: Dover Publications, Inc., 1967), 23; bandingkan dengan, Mulyadi Kartanegara, "Metodologi Kajian Filsafat Islam”, dalam Refleksi, Jurnal Fakultas Ushuluddin, Vol. I, No. 1, 1998, 4

${ }^{27}$ Hadis riwayat Ahmad dalam Musnad al-Anshar menuturkan pertanyaan Abu Zarr kepada Nabi saw.: Aku (Abu Zarr) bertanya, "Berapakah jumlah rasul ya Rasulullah?" Nabi saw. menjawab, "tigaratus limabelas orang jumlahnya."

${ }^{28} \mathrm{Al}$-Qur'an, surah al-Ghafir [40]: 78

${ }^{29} \mathrm{Al}-\mathrm{Qur}$ 'an, surah al-Nahl [16]: 17

${ }^{30} \mathrm{Al}-\mathrm{Qur}$ 'an, surah al-Ra'd [13]: 7

${ }^{31} \mathrm{Al}$-Qur'an, surah al-Fatr [35]: 24

${ }^{32}$ Lihat, Nurcholish Madjid, "Kata Pengantar" dalam Passing Over Melintasi Batas Agama (Jakarta: Gramedia, 1998), xxx dan 390. 
banyak beberapa kali lipat dari itu, dan bahkan sebuah riwayat menyebutkan sampai 124.000 orang nabi.

Jadi, berangkat dari latar belakang di atas, di sini perlu ditegaskan (sebelum lebih lanjut) bahwa sumber dan pangkal tolak filsafat dan ilmu dalam Islam adalah ajaran Islam itu sendiri, sebagaimana "spiritnya" terdapat dalam al-Qur'an dan Hadis. Al-Qur'an secara esensial memang merupakan kitab keagamaan, dan bukan kitab filsafat. Akan tetapi, menurut Syarif, alQur'an secara keseluruhan menyangkut masalah-masalah agama dan filsafat." ${ }^{33}$ Di samping itu, al-Qur'an dan Hadis juga, menurut Azra, memberikan "iklim yang kondusif dan atmosfir yang khas dalam mendorong aktifitas intelektual dan bagi pengembangan ilmu pengetahuan Islam. ${ }^{34}$

Untuk itu, sulit dipahami, kata C.A. Qadir --sabagaimana kutip oleh Cak Nur-- kalau ada penilaian bahwa filsafat (juga sains Islam) adalah carbon copy pemikiran Yunani atau Hellenisme. Meskipun filsafat Islam memiliki dasar yang kokoh dalam sumber ajaran Islam sendiri, filsafat dan sains dalam Islam, tidak dapat dipungkiri, banyak mengandung unsur-unsur dari luar, terutama dari pemikiran Yunani dan Hellenisme. Di sinilah pangkal kontroversi dalam filsafat: sejauh mana agama Islam membolehkan masuknya unsur-unsur dari luar, terlebih jika datangnya tidak saja dari kalangan "ahl kitab", seperti Yahudi dan Nasrani, tetapi malah dari orang-orang Yunani kuno yang pagan. ${ }^{35}$

Sebenarnya, masalah ini tidak perlu dipersoalkan amat oleh ummat Islam, karena "bagi orang yang mencari kebenaran", kata al-Kindi, "tidak ada nilai yang lebih tinggi dari kebenaran itu sendiri." Mencari kebenaran selagi itu merupakan kebenaran dan hikmah, umat Islam harus mengambilnya, seperti sabda nabi saw., "Hikmah adalah barang hilangnya kaum beriman, maka siapa saja mendapatinya hendalah ia memungutnya", sebagaimana kutipan epigraf di awal tulisan ini.

\section{Wacana Keilmuan: Hellenisme Islam Era Awal Mutakallimin}

Kelahiran Islam lewat pewahyuan (610-632) pada figur Nabi Muhammad saw. sangatlah tepat-ruang dan pas-waktu. ${ }^{36}$ Maka dalam waktu

\footnotetext{
${ }^{33}$ Penegasan mengenai al-Qur'an sebagai sumber dan titik tolak ilmu dan filsafat dalam Islam, misalanya lihat, M.M. Sharif, "Philosophical Teacings of the Qur'an" dalam M.M. Sharif (ed.), A History of Muslim Philosophy (Delhi: Low Price Publications, 1961), Vol. I, 136

${ }^{34}$ Azyumardi Azra, Pendidikan Islam Tradisi dan Modernisasi, 13.

${ }^{35}$ Nurcholish Madjid, Islam Doktrin dan Peradaban, 218-219.

${ }^{36}$ Disebut "tepat-ruang" karena Mekkah dan Madinah (jazirah Arab umumnya) relatif "jauh" dari jangkauan kekuasaan dan pertikaian dari dua negara adi-kuasa: Kekaisaran Romawi dan Khousru Persia. Dikatakan "pas-waktu" karena saat itu kedua negeri super power tersebut semakin melemah akibat peperangan yang berkesenantiasa antara mereka. Sehingga, menurut J.J. Saunders, "andaikata Islam lahir seabad sebelumnya, maka kaisar Yustianus (Romawi) yang kuat pada era itu akan menghalangi penyebaran Islam. Apabila seabad setelahnya, barangkali Arabia telah memeluk agama Kristen karena kekuatan Byzantium dan
} 


\section{\begin{tabular}{r|r} 
Diskursus Keillmuan: & 9 \\
Sejarah Transmisi Filsafat Hellenisme dalam Filsafat Islam &
\end{tabular}}

yang relatif singkat (lamanya hanya 23 tahun) Nabi Muhammad saw. berhasil dengan sangat mencengangkan dalam mengemban tugas dan misi dari Allah. Sepeninggalan Nabi Muhammad saw (w. 632) keberhasilan-keberhasilan dalam Islam menyiarkan agama dilanjutkan pula dengan tidak kalah gemilang oleh Khalifah al-Rasyidu>n. Agama Islam yang masih "remaja” ini merambah ke mana-mana untuk melakukan "pembebasan" (futuhat) di provinsi-provinsi jajahan dua adi-kuasa: Kekaisaran Romawi dan Khousru Persia, seperti Syiria, Irak, Mesir. Bahkan belakangan kedua ibukota negeri super power tersebut juga mampu ditaklukkan oleh tentara Islam. ${ }^{37}$ Dengan jatuhnya kota Iskandaria pada 651 di tangan jenderal Amru bin 'Ash menandai rampungnya penaklukan Islam terhadap Timur Dekat, sekaligus berakhirnya kekuasaan Persia dan Byizantium di wilayah tersebut. ${ }^{38}$ Kurang dari lima puluh tahun berikutnya tentara Islam menaklukan Spanyol di belahan Barat dan India di Timur. ${ }^{39}$

Persia telah pulih kembali." Pada bagian lain, Saunders melanjutkan pengandaiannya, "andaikan saja Abraham berhasil benguasi Mekkah, maka seluruh jazirah Arab akan terbuka untuk penerobosan Kristen dan Byzantium. Akibatnya, tanda Salib akan menjulang tinggi di atas Ka'bah; dan Muhammad mungkin akan mati sebagai pastur atau pendeta." Lihat, J.J. Saunders, A History of Medieval Islam (London: Reutledge, 1965), 14-15 dan 36-37. Ini hanya sekedar pengandaian. Dan sejarah tidak dapat diajak berandai-andai, disebut sejarah karena ia adalah peristiwa masa lalu yang real terjadi dan memiliki fakta dan data kuat dan akurat.

${ }^{37}$ Lihat, Marshall G.S. Godgson, The Venture of Islam Conscience and History in a World Civilization (New York \& London: The Univrsity of Chicago Press, 1961), 197-206.

${ }^{38}$ Setidaknya, menurut Majid Fakhri, ada dua alasan kenapa penaklukan Islam begitu mudah dilancarakan: pertama, upaya perluasan dilakukan oleh kekaiasaran Romawi, Heraklius pada 610 mengakibatkan timbulnya pertarungan dahsyat antara orang-orang Persia dan Byzantium yang sebelumnya telah berjibaku dalam peperangan panjang guna menancapkan pengaruh militer mereka di Timur Dekat. Peristiwa perang berkepanjangan di antara mereka mengakibatkan melemahnya kekuatan masing-masing, sehingga tentara Islam dengan mudah mencatat serangkai kemenangan demi kemenangan dari kedua bala tentara yang jumlahnya lebih banyak dan sangat terlatih; dibandingkan dengan tentara Islam yang jumlahnya sedikit, ditambah belum berpengalaman dalam medan peperangan besar. Kedua, faktor perbedaan dan pertentangan keagamaan yang melibatkan kaum Nestorian, Monofosit dan Melchite (aliran ortodoks) mengakibatkan rasa tidak senang dan aman bagi penduduk Mesir, Syiria dan Irak. Dalam kondisi demikian, tidaklah aneh kalau kedatangan orang-orang (tentara-tentara) Islam disambut dengan suka cita sebagai "pembebas" (futuhat). Dan sebagian besar berharap bahwa orang-orang Islam dapat menghilangkan penindasan dari Konstantinopel dengan alasan demi menjaga ajaran-ajaran ortodoksi, khususnya masa pemerintahan Justinian (527-565). Lihat, Majid Fakhri, A History of Islamic Philosophy, 12-13.

${ }^{39}$ Lihat, Howard T. Turner, Science in Medieval Islam (Austin: The University of Texas Press, 1961), 5. Bahkan tentara Islam mampu menyeberangi pegunungan Pyrene. Tetapi belakangan, ketika pemerintahan Islam di Andalusia tidak pernah sunguh-sungguh lagi untuk menyeberangi pegunungan itu guna menaklukan Prancis. Karena dalam persepsi ummat Islam pada saat itu bahwa daerah-daerah di sebelah utara itu terlalu dingin dan tidak cocok untuk mengembangan peradaban; dan manusianya terlalu kasar dan bodoh. Lihat, Nurcholish Madjid, Kaki langit Peradaban, 10; bandingkan Bernard Lewis, Muslim Discovery of Europe (New York \& London: W.W. Norton \& Company, 1982), 8. 
Pada awal perkembangan Islam, lewat bimbingan langsung dari Nabi Muhammad saw di Madinah, umat Islam (generasi sahabat) terpesona oleh kesucian al-Qur'an dan sabda Nabi --terpokus mengabdian diri mereka dalam mengambil pelajaran semata-semata pada kandungan al-Qur'an dan prilakuperkataan Nabi saw. Belakangan, konsekwenasi dari kecenderungan seperti itu melahirkan ilmu-ilmu bidang sirah (Nabawi), Hadis, Tafsir dan fiqh serta cabang-cabang ilmu bahasa, misalnya tata-bahasa dan retorika. Ilmu-ilmu ini yang, sama sekali berbeda dengan ilmu filsafat-rasionl, dimaksudkan sebagai alat untuk memahami al-Qur'an dan Hadis. Sikap ganerasi Islam semacam itu dapat dimengerti karena orang-orang Arab (dijazirah Arabiah) tidak memiliki tradisi keilmuan dan filsafat Hellenisme. ${ }^{40}$

Walau demikian, ini tidak berarti bahwa di kalangan orang-orang Arab kegiatan mencari ilmu-ilmu "duniawi" [dengan terpaksa menggunakan term ini] tidak berjalan sama sekali. Karenanya. teori lama yang menyatakan bahwa "orang-orang Muslim awal adalah musuh bagi ilmu pengetahuan dan sains, dan bahwa mereka hanya mau menerima ilmu pengatahuan yang berasal dari Qur'an dan Hadis" adalah salah dan pendapat yang tidak memiliki landasan sejarah. ${ }^{41}$ Kenyataan sejarah menunjukah sebaliknya bahwa pada masa-masa awal Islam, kendatipun hanya di kalangan sangat terbatas, ada juga di antara mereka pergi ke luar daerah untuk menuntut ilmu. ${ }^{42} \mathrm{H}\{$ arith bin Kalardah (w. 634) dari T\{aif, menurut Philip K. Hitti,

\footnotetext{
${ }^{40}$ Sebelum era kelahiran Islam, orang-orang Arab tidak mengenal pemikiran Hellenisme karena mereka tidak menaruh perhatian pada ilmu dan filsafat serta peradaban yang datang dari negeri-negeri tetangga, seperti dibawa oleh orang Mesir kuna, Persia, India dan Yunani kuna. Menurut Fuad al-Ahwani, bagaimana mungkin orang-orang Arab mengenal pemikiran filsafat dan ilmu pengetahuan, jika kenyataannya mereka tidak menaruh perhatian sama sekali pada syarat utama diperlukan untuk mengenal ilmu dan peradaban walau hanya secara teoritis, yaitu mencatat dan menulis buku untuk mengabadikan kemajuan pemikiran yang mereka terima dari satu generasi ke genarasi berikutnya sebagai pusaka pemikiran. Lihat, Fuad al-Ahwani, Filsafat Islam, 1-2. Selain itu, orang-orang Arab sangat terkenal akan kecerdasan dan kekuatan daya hafal, sehingga mereka tidak memiliki tradisi tulis-menulis. Bagi mereka adalah kenaifan dan kehinaan kalau mereka menyatakan pemikirannya lewat tulisan; dan merupakan suatu kebanggaan dan kehormatan kalau mereka menyatakan lewat lisannya. Ilmu dan pengatauan, menurut mereka, letaknya ada dalam dada dan bukan pada tulisan (al-ilm fi al-sudurr wa la fi al-suturr). Untuk itu, kalau ada orang Arab yang kedapatan sedang menulis, maka ia akan mewanti-wanti untuk tidak memberitahukan halanya itu kepadda orang lain.

${ }^{41}$ Lihat, Mehdi Nakosteen, Konstribusi Islam atas Dunia Intelektual Barat Deskripsi Analisis Abad Keemasan Islam, Surabaya: Risalah Gusti, 2003, 17.

${ }^{42}$ Contoh lain dari hubungan orang-orang Arab dengan dunia luar dalam bidang ilmu pengetahuan, misalnya, dilakukan oleh Nazdr Ibn H\{arist Ibn Kala>dah. Ia, anak saudara ibu Nabi saw., pernah merantau seperti ayahnya, ia bergaul dengan golongan cerdik-pandai dan pendeta-pendeta agama Keisten serta ia berhasil mendapatkan ilmu-ilmu kuna sangat berharga. Ia mempelajari filsafat, kata-kata hikmah, dan ia juga mengambil ilmu kedokteran dari ayahnya. Dikatakan bahwa al-Nazdr adalah penyokong perlawanan yang dilakukan oleh Abu Sufyan terhadap Nabi saw. Ia beranggapan, dengan arogansinya, bahwa ilmu serta
} 


\section{Diskursus Keillmuan: $\mid 11$ \\ Sejarah Transmisi Filsafat Hellenisme dalam Filsafat Islam}

adalah orang pertama yang didik secara ilmiah dan menempati urutan teratas dari daftar dokter-dokter Arab pada abad pertama Islam. Ia belajar ilmu kedokteran pada salah satu perguruan di Jundisapur, Persia; dan belakangan memperoleh gelar kehormatan sebagai "dokter orang Arab." ${ }^{43}$

Prihal profesi $\mathrm{H}\{$ arith bin Kala`dah sebagai dokter direkam dalam hadis Nabi saw. bahwa ada suatu riwayat berasal dari Said bin Abi Waqqas menyatakan ketika ia menderita sakit, Rasulullah menjeguknya. Saat itu Nabi bersabda, "Datanglah kepada Harist bin Kaldah karena ia tahu soal kedokteran. ${ }^{44}$ Akan tetapi, orang Arab sezaman dengan Nabi saw. sebagaian besar masih skeptis terhadap ilmu kedokteran asing itu. Orang-orang Arab, khususnya sahabat Nabi saw., masih lebih yakin terhadap ucapan Nabi saw. mengenai kedokteran, hegiene, diet dan sebagainya. Mereka menuruti dan menaati ucapan Nabi saw. dengan sepenuh hati; dan ini sekaligus merupakan ciri utama generasi Muslim awal. ${ }^{45}$

Selaras dengan itu, meskipun generasi Islam awal begitu terpesona kepada kitab suci dan figur Nabi saw., tetapi ini tidak menutup kemungkinan bahwa pada masa itu terdapat juga pencarian ilmu pengetahuan "duniawi". Ada penuturan, misalanya, bahwa pada masa Nabi saw. diutus beberapa sahabat untuk belajar ilmu kedokteran di perguruan Jundisapur, Persia. Kebenaran ini sangatlah logis, mengingat anjuran Nabi saw., "ut\}lub al-'ilma wa lau bi al-sìn" (tuntutlah ilmu walaupun [sampai] ke negeri Cina). ${ }^{46}$ Artinya, jangankan ke Persia relatif lebih dekat jarakanya dari jazirah Arab, bahkan "walaupun" sampai ke negeri Cina yang begitu jauh di belahan timur Nabi saw menganjurkannya untuk menuntutnya. Bukan itu saja, Nabi saw. juga memerintahkan beberapa sahabat untuk mempelajari bahasa Ibrani (Hebraw). ${ }^{47}$ Namun, perintah Nabi saw. ini hanya berlaku secara "eksklusif" di kalangan sahabat, sehingga tidak memperlihatkan resonansi yang signifikan. Di samping itu, kegiatan semacam ini, sebagaimana disebutkan

keahlian dapat mengalahkan kenabian. Lihat, Ahmad Amin, Fajr al-Islam (Kairo: Makthabah alNahdha al-Mishriyah, 1975), 133.

${ }^{43}$ Lihat, Philip K. Hitti, History of the Arab, London: Macmillan Press, 1970,

${ }^{44}$ Meskipun begitu, ilmu pengetahuan dalam bidang kedokteran, menurut Fuad alAhwani, belum dapat dianggap memadai karena ia belum menguasi ilmu kedokteran secara ilmiah. Lihat, Ahmad Fuad al-Ahwani, Filsafat Islam, 35.

${ }^{45}$ Seyyed Hossein Nasr, Science and Civilization in Islam, 192.

${ }^{46}$ Hubungan Islam dengan daratan Cina belakangan terlihat dengan adanya unsur sains Cina dalam Islam. Menurut Nasr, besar dugaan bahwa terdapat unsur Cina dalam Islam, terutama dalam al-khemi yang menunjukkkan beberapa hubungan waktu lalu antara sarjana Muslim dengan saintis Cina. Beberapa orang lebih jauh lagi menyatakan, sungguhpun tanpa bukti memadai, bahwa kata al-kimiyah --dari sini kata al-khemi diturunkan-- adalah pengaraban dari kata Cina kuna Chin-I yang dalam beberapa dialek terbaca Kim-Ia dan berarti "sari pembuat emas". Tetapi pengaruh lebih besar dari Cina kepada Islam pada abad-abad kemudian, khususnya setelah penyerbuan bangsa Mongol, teruma dalam bidang seni dan teknologi. Lihat, Seyyed Hossein Nasr, Science and Civilization in Islam, 31-32.

${ }^{47}$ Nurcholish Madjid, Islam Agama Kemanusian (Jakarta: Paramadina, 1995), 51-52. 
sebelumnya, "tenggelam" di dalam keseriusan sahabat Nabi saw. untuk menekuni ilmu bersumber pada wahyu-wahyu Ilahi dan sunnah-sunnah langsung di sisi Nabi saw. tercinta. Atau jangan-jangan hadis-hadis Nabi untuk menekuni ilmu rasional-spekulatif ("duniawi”) sengaja dihilangkan sewaktu dilakukan kodifikasi Hadis. ${ }^{48}$

Kemudian, setelah generasi Islam pertama (sahabat), umat Islam sudah tidak lagi terkonsentrasi di kota Madinah, tetapi sudah tersebar diberbagai daerah, seperti di Mesir, Syiria, Irak dan Persia. Di daerah-daerah ini, khususnya di Syiria, jauh sebelum datangnya Islam terdapat tradisi intelektual yang canggih dan merupakan kantong-kantong pemikiran Hellenisme. Di sana umat Islam dengan sendirinya terpaksa melakukan interaksi intelektual dengan penduduk tempatan, termasuk dengan orangorang Nasrani Nestoria yang dikenal terpelajar. Dari interaksi tersebut tidak jarang doktrin dan pemikiran, seperti ide-ide qadariyah, masuk ke Islam dari latar belakang Hellenisme Kristen. ${ }^{49}$

Lebih dari itu, dalam melakukan interaksi sosial-intelektual umat Islam acap kali berbenturan dengan persoalan-persoalan yang, secara harfiah, tidak ditemukan dalam al-Qur'an dan tidak didapatkan dalam Hadis Nabi saw. Kondisi seperti ini memaksa sebagai umat Islam terpelajar (ulama) untuk meresponinya dengan menggunakan analogi (qiyas) dan pemikiran secara independen $\left(\mathrm{ra}^{\mathrm{y} y u}\right)^{50}$ bahkan kalau diperlukan dengan interpretasi allegoris (ta'wi $>$ ). Artinya pendekatan tekstual terhadap kitab suci (begitu juga dengan Hadis Nabi saw.) sudah mulai tidak relevan. Karenanya, harus diganti dengan pendekatan kontekstual dan penafsiran secara tamsil al-ibarrah

${ }^{48}$ Berkenaan dengan ini, banyak indikasi menunjukkan, bahwa Islam pada masa klasik telah terlibat dalam perdebatan cukup luas dan ramai, dalam suasana kehidupan intelektual yang lebih bebas dan terbuka daripada masa-masa sesudahnya. Sehubungan dengan ini Nurcholish Madjid, mengatakan: "Agaknya pada dua abad pertama Islam banyak beredar hadis-hadis yang menjunjung tinggi akal. Tetapi karena hadis-hadis itu lebih mendukung "kaum liberal", maka dalam perkembangan lebih lanjut dikenakan prasangka sebagai lemah dan tidak sah. Sehingga tidak banyak dimuat dalam kitab-kitab hadis hasil pembukuan masamasa sesudahnya. Sebagai contoh, adalah seorang pemikir Islam, al-Harits ibn Asad alMuhasibi, wafat pada $243 \mathrm{H}$ (tujuh puluh tahun sebelum wafat al-Bukhari). Dia adalah salah seorang tokoh "rasionalis" yang sangat dini dalam Islam, meninggalkan karya-karya tulis sistematis. Dia juga seorang agamawan yang saleh dengan kecenderungan kesufian yang kuat". Dalam karya-karyanya, menurut Nurcholish Madjid, al-Muhasibi menuturkan hadits-hadits yang sangat mengesankan tentang akal. Al-Muhasibi menolak pandangan sebagian ulama yang menyatakan bahwa hadis-hadis tentang akal itu palsu ( $m a w d\} u^{c}$ ), bikin-bikinan atau sekurangkurangnya lemah (d\}a $\left.a^{i} i f\right)$. Baginya, hadits-hadits itu adalah absah, karena maknanya sejalan dengan berbagai gambaran dan ajaran al-Qur'an. Dan hadis-hadis itu cukup menggambarkan suasana yang memberikan dorongan kepada kaum muslim klasik untuk menjunjung tinggi akal dan pemikirkan rasional. Lihat, Nurcholish Madjid, Kaki Langit Peradaban Islam, 49-50.

${ }^{49}$ Fazlur Rahman, Gelombang Perubahan Dalam Islam Study Tentang Fundamentalisme Islam (Jakarta: PT. Raja Grafindo Persada, 2000), 61.

${ }^{50}$ Majid Fakhri, A History of Islamic Philosophy, 3. 


\section{Diskursus Keillmuan: \\ Sejarah Transmisi Filsafat Hellenisme dalam Filsafat Islam}

(perempuan dengan menyeberangi makna harfiahnya). Majid Fakhri memaparkan:

Pendekatan yang sempit atas persoalan-persoalan yang muncul dari kajian-kajian ayat-ayat al-Qur'an, ternyata tidak dapat bertahan lama terhadap tekanan-tekanan waktu. Pertama, pertentangan dini yang tak terelekkan antara Islam dengan paganisme dan Kristen baik yang ada di Demaskus ataupun di Baghdad serta ketegangan-ketegangan yang ditimbulkannya. Kedua, terdapatnya persoalan-persoalan moral dan hukum yang disebabkan oleh gambaran-gambaran yang tidak jelas menyangkut kekuasaan Tuhan yang tidak terbatas di dunia ini, sebagaimana dipaparkan dalam al-Qur'an dan hubungannya dengan pertanggungjawaban manusia. Dan akhirnya, terdapat kebutuhan sangat mendesak guna melindungi apa yang disebut kesatuan pandangan hidup Islam, yang tidak dapat dibangun tanpa upaya-upaya sistematis dan penyelesaian keterangan wahyu (al-Qur'an dan hadis) yang saling bertentangan dalam keharmonisan maknawi. ${ }^{51}$

Pergumulan terhadap persoalan-persoalan krusial tersebut, lagi-lagi menurut Majid Fakhri, menjadi dasar pertumbuhan dan perkembangan teologi dalam Islam. ${ }^{52}$ Perbincangan diseputar masalah-masalah krusial itu, setidak-tidaknya, menurut Ameer Ali, telah muncul pada era seorang sarjana Islam liberal dan rasional, yaitu Ja'far al-S\}ardik [seorang yang sangat terpelajar dan keturunan langsung dari Nabi Muhammad saw $].{ }^{53}$ Berikutnya

${ }^{51}$ Majid Fakhri, A History of Islamic Philosophy, 4-5.

${ }^{52}$ Boleh jadi Majid Fakhri betul bahwa persoalan-persoalan krusial disebut di atas telah menjadi dasar peertumbuhan dan perkembangan teologi Islam pada era selanjutnya. Akan tetapi, yang pasti, munculnya teologi dalam Islam (Ilmu Kalam, setidaknya menurut Harun Nasution [alm. Semoga Tuhan senantiasa merahmati dan meerahiminya], justru disebabkan oleh persoalan-persoalan politik, entri pointnya pada persoalan pengganti (khalifah) setalah wafatanya Nabi saw; dan stressing pointnya pasca perang Siffin antara Khalifah Ali bin Abi Thalib dan Muawiyah bin Abu Syfyan. Lihat, Harun Nasution, Teologi Islam, 1-11; Islam Ditinjau dari Berbagai Aspeknya (Jakarta: UI-Press, 1987), 92; lihat juga Philip K. Hitti, History of The Arab (London: Macmillan Press, 1970), 182. Tentang pengangkatan khalifah setelah wafatnya Nabi saw., misalnya lihat, Mumtaz Ahmad (ed.), State, Politics and Islam (Indianapolis: American Trusst Publication, 1986), 42; mengenai term "khalifah" lihat, Bernard Lewes, The Political Leanguage Islam (Chicago: University of Chicago Press, 1989z), 44.

${ }^{53}$ Ia merupakan kepala keturunan Nabi Muhammad. Ja'far al-Shadik adalah seorang yang sangat rasionalis dan liberal. Ia seorang yang sangat terpelajar, seorang penyair, filosuf dan rupa-rupanya ia menguasa beberapa bahasa asing. Karenanya, ia acap kali berhubungan dengan sarjana dan budayawan dari kalangan agama Kristen, Yahudi dan Zoroaster; dan dengan mereka ia sering melakukan dialog-dialog dan bertukar pikiran. Ja'far al-Shadik merupaan bapak rasionalisme dalam Islam di mana Abu Hanifah dan Imam Malik pernah berguru. Sehingga dari kedua muridnya ini sangat terlihat sekali pengaruh dan unsur rasionalitasnya dalam membangun sistem hukum yang mereka kembangkan, terutama sekali tampak pada diri Abu Hanifah. Lihat, Ameer Ali, The Spirit of Islam (Delhi: Idarah-I Adabiyah-I Delhi, t.t.), 411. 
sikap keterpelajaran ini dilanjutkan Hasan Basri ${ }^{54}$ serta Washil bin Atha', pendiri aliran rasionalisme secara formal, Mu'tazilah. ${ }^{55}$ Dan menurut Nasr, aliran ini merupakan teologi sistematis pertama dalam sejarah pemikiran teologi Islam. ${ }^{56}$

Dorongan kuat untuk berpikir sistematis tentang dogma-dogma agama, menurut Rahman, menuntut aliran ini melakukan rasionalisasi semakin lama semakin intens. ${ }^{57}$ Guna mengembangkan rasionalisasi dalam Islam, aliran Mu'tazilah banyak dipengaruhi dan dengan mengambil metode filsfat Yunani yang rasional dan liberal. Ada dua alasan yang, menurut Abu Zahra, mendorong orang Mu'tazilah untuk mempelajari filsafat. ${ }^{58}$ Pertama, mereka menemukan dalam filsafat Yunani keserasian dan kecenderungan pikiran mereka. Dengan mengambil metode berpikir seperti itu membuat mereka menjadi lancar dan kuat dalam berargumentasi. Kedua, mereka mempelajari metode berpikir filsafat untuk menyanggah dan menolak pihakpihak lain berusaha meruntuhkan dasar-dasar ajaran Islam dengan argumentasi logis dan rasional..$^{59}$

Pada gilirannya, dalam merespon persoalan-pesoalan di atas meniscayakan argumen-argumen lebih bernas, yang sepertinya, musykil untuk dirahi tanpa menggunakan argumen-argumen filosofis dan dukungan

\footnotetext{
${ }^{54}$ Pada masanya ia salah seorang guru besar yang paling terkenal, dan termasuk golongan yang anti predistinasi. Ia adalah seorang kelahiran Madinah, dan konon, ia disusui oleh salah seorang dari istri Rasulullah. Ketika ia remaja, menurut Ameer Ali, ia benar-benar pernah duduk bersama dengan keluarga dan keturunan Nabi dan menghirup pemikiran liberal dan rasional darinya. Dan ketika belakangan tinggal di Basrah, ia membuka halaqah-halaqah yang segera dikerumuni oleh peserta didik, termasuk dari Irak. Dan di antara muridnya yang terkenal adalah Abu Huzaifah Washil bin Atha', belakangan menjadi pencetus lahirnya aliran teologi Mu'tazilah. Ameer Ali, The Spirit of Islam, 414.

${ }^{55}$ Ameer Ali, The Spirit of Islam, 414.

${ }^{56}$ Seyyed Hossein Nasr, Intelktual Muslim: Teologi, Filsafat dan Gnosis (Yogyakarta: Pustaka Pelajar, 1996), 42.

${ }^{57}$ Fazlur Rahman, Islam (Jakarta: Bumi Aksara, 1992), 138.

${ }^{58}$ Namun, masuknya filsafat Yunani dalam sistem pemikiran kalam, menurut Nurcholish Madjid, sangat disayangkan. Ilmu kalam dibandingkan dengan filsafat, lagi-lagi menurut Nurcholish madjid, jauh lebih orisinil, dan diangagp bentuk paling referesentatif pemikiran spekulatif Islam. Tetapi kecenderungan meminjam dan menggunakan metodemetode filasfat Yunani untuk mengembangkan argumen-argumennya itu telah menjadi sumber pencemarannya, sehingga sejak tahap awal penggunaan Ilmu Kalam oleh kaum Mu'tazilah ini ditentang oleh para ulama. Bahkan meskipun Ilmu kalam Asya'ariyah kini diterima secara taken for granted akan keabsahannya, tetapi ia harus menunggu dua abad lamanya hingga datangnya al-Ghazali. Dan selama itu, Asy'ariyah juga menjadi sasaran polemik dan kontroversi. Nurcholish Madjid, Tradisi Islam (Jakarta: Paramadina, 1997), 113.

${ }^{59}$ Lihat, Muhammad Abu Zahra, Aliran Poitik dan Aqidah dalam Islam (Jakarta: Logos Publishing Hoese, 1996), 156. Ketika Hasan Hanafi menjelaskan akar krisis dunia Islam, ia menawarkan agar menghidupkan ulang semangat liberalisme dan rasionalisme Mu'tazilah. Lihat, Kazou Shiniogaki, Kiri Islam: Antara Modernisme dan Postmodernisme (Yogyakarta: LkiS, 1993), 45.
} 


\section{Diskursus Keillmuan: Sejarah Transmisi Filsafat Hellenisme dalam Filsafat Islam}

logika Yunani. Karenanya, perbincangan teologis itu memaksa dan mendorong mutakallimin Mu'tazilah dan sebagian orang Islam terpelajar untuk melakukan interaksi intelektual dengan dunia pemikiran Hellenisme, terutama dengan orang-orang Kristen Nestorian yang berdiam di Iskandaria (Mesir), Demaskus, Antioka dan Ephesus (Syiria), Harran (Mesopotamia dan Jundisapur). Pada saatnya nanti, di tempat itulah lahir dorongan pertama kegiatan penelitian dan penerjemahan karya filsafat dan ilmu Yunani kuna.

\section{Wacana Keilmuan: Dari Yunani Lewat Iskandaria-Syiria- Jundisapur ke Islam}

Jauh sebelum datangnya agama Islam, daerah-daerah (kota-kota) tersebut di atas telah menjadi pusat dan pengembangan filsafat dan ilmu pengetahuan Hellenisme warisan dari Yunani kuno selama berabad-abad. Kota Iskandaria ${ }^{60}$ pada abad ketiga SM. merupakan kota pertama penyemaian serta sekaligus menjadi pusat dan marcusuar filsafat dan ilmu pengetahuan warisan Yunani kuno. Dalam kondisi seperti inilah kota Iskandaria menjadi titik pertemuan Hellenisme dengan pengaruh dari Timur dan Mesir kuno. Kota Iskandaria memiliki kekayaan terpenting dan paling berharga, yaitu perpustakaan yang dipenuhi dengan jenis buku-buku ilmiah dari berbagai disiplin dan cabang ilmu pengetahuan yang ada pada saat itu. Dalam perpustakaan itu untuk pertama kalinya umat manusia mengumpulkan dengan penuh kesungguhan dan sistematis pengetahuan apapun tentang dunia ini. ${ }^{61}$

Sementara itu kegiatan keilmuan di kota Iskandaria pada umumnya, dan perpustakaan Iskandaria pada khususnya sangat semarak. Dari kegiatan itu, misalnya, muncul konsep tantang "cosmos" dalam bahasa Yunani berarti "harmonis", kebalikan dari "chaos" artinya "kekacauan". Dan mereka menyebut alam raya ini cosmos karena, menurut mereka, alam raya dalam keserasian. Dari kajian tersebut melahirkan sejumlah ilmuan dengan hasil penemuannya masing-masing, seperti diungkapkan oleh Carl Sagan, sebagaimana dikutip oleh Nurcholish Madjid:

Kemudian Iskandaria tampil banyak ahli ilmu pengetahuan yang lain, seperti Hipparchus yang mencoba membuat peta konstelasi bintangbintang dan mengukur tingkat cahaya bintang-bintang itu; lalu Euclidus, penemu sebanarnya ilmu ukur atau geometri; kemudian Dionysius, yang meneliti organ-organ suara manusia dan meletakkan teori tentang bahasa; Herophlius, ahli ilmu faal atau fisologi yang

\footnotetext{
${ }^{60}$ Kota Iskandaria atau sering pula disebut dengan ejaan "Aleksandaria" didirikan oleh Iskandar Agung --murid filosuf "guru pertama", Aristoteles-- dari Macedonia. Nama kota ini diambil dari nama pendirinya, Iskandar Agung/ Alexander the Great. Iskandar Agung tidak saja mengharagai ilmu pengetahuan dan filsafat serta agama-agama berbagai bangsa, malah ia juga menganjurkan para tentaranya untuk kawin dengan wanita-wanita Persia dan India. Berkat jiwa ketebukaannya itu kota yang didirikannya segera menjadi pusat ilmu pengetahuan bagi umat manusia. Lihat, Nurcholish Madjid, Islam Doktrin dan Peradaban, xxvi.

${ }^{61}$ Nurcholish Madjid, Islam Doktrin dan Peradaban, xxvi
} 
menegaskan bahwa organ berpikir manusia bukanlah jantung seperti saat itu diyakini, melainkan otak; Heron, penemu rangkaian roda gigi dan mesin uap kuna, pengarang buku Automata, sebuah buku pertama tentang robot; Apollonius, yang meletakkan teori tentang bentukbentuk melengkung seperti elips, parabola dan hiperbola; Archimedes, genius mekanik yang terbesar sebelum Leonardo de Vinci; Ptolemy, seorang yang meskipun teorinya tentang alam raya ternyata salah (geosentris) namun semangat keilmuannya banyak memberi ilham. ${ }^{62}$

Kesemarakan pengkajian ilmu pengetahuan di kota Iskandaria pada abad keempat berada dibawah "bayang-bayang kegelapan" karena di kalangan Gereja Kristen sedang melakukan konsolidasi diri dan berusaha untuk mengikis budaya dan pengaruh paganisme. Beberapa ilmuan dicurigai dan diawasai, dan bahkan pada akhirnya, di antara mereka ada yang dibunuh. Salah satu korbannya, misalanya ialah seorang wanita bernama Hypetia yang, tidak saja pintar (ahli matematika dan astronomi) tetapi juga teramat cantiknya, dibunuh dengan sangat sadis dan menyedihkan; lalu dibakar bersama perpustakaan yang dimilikinya pada tahun $415 .{ }^{63}$ Tidak lama sesudah itu, perpustakaan Iskandaria yang hebat itu pun juga tidak luput dari sikap picik dan fanatisme agama, dan atas perintah Uskup Agung Iskandaria, dibakar habis berserta isinya. ${ }^{64}$

Awalnya warisan Yunani kuno datang dari Iskandaria --belakangan tidak kondusif lagi-- lalu pindah ke Antioka dan dari sana ke Nisbis, Endessa (Ruha) dan Harran yang dibawa oleh orang-orang Nasrani aliran Monophysit ${ }^{65}$ dan Nestorian. ${ }^{66}$ Aliran Nasrani yang disebut terakhir ini

${ }^{62}$ Nurcholish Madjid, Islam Doktrin dan Peradaban, xxvi-xxvii.

${ }^{63}$ Hypetia dilahirkan pada 370 Masehi. Carl Sagan menuturkan sebagaimana dikutip oleh Nurcholish Madjid bahwa wanita ini menolak semua lamaran dari lak-laki kerena ia ingin mengabdikan dirinya dan mencurahkan perhatinnya sepenuhnya kepada ilmu pengetahuan. Tetapi cita-cita dan hasrat muliannya itu tidak dapat berlanjut karena pada usia 45 tahun ia dicegat oleh segerombolan kaum fanatik Kristen dalam perjalanan ke perpustakaan, dia diturunkan dari kereta kudanya, lalu dibunuh dengan cara mengelupasi dagingnya dari tulangnya kemudian dibakar bersama apa yang dia miliki Nurcholish Madjid, Islam Doktrin dan Peradaban, xxviii.

${ }^{64}$ Dengan peristiwa itu, Carl Sagan berandai, "kalau saja perpustakaan Iskandaria tidak menjadi koraban fanatisme agama, tradisi keilmuannya terus berlanjut, maka barangkali Eistein sudah tampil lima abad yang lalu. Atau mungkin malah seorang Einstein tidak (perlu) pernah ada, sebab perkembangan ilmu pengetahuan integral dan menyeluruh sudah terjadi. Dan mungkin pada abad dua puluh Masehi ini, sedikit saja orang yang tinggal di bumi karena sebagian besar telah menjelajah dan mengoloni bintang-bintang dan telah beranak pinak sampai milyaran jiwa!" Lihat, Nurcholish Madjid, Islam Doktrin dan Peradaban, xxx.

${ }^{65}$ Aliran ini berpendirian dengan mempercayai konsep ketuhanan "trinitas", Tuhan (Bapak), Yesus (Anak) dan Ruh al-Qudus; dengan kata lain Lahut, Nasut dan Kalimah. Baginya ketiga unsur ketuhanan tersebut tetap eksis (dan tetap berbeda satu dengan yang lainnya), meskipun ketiga unsur tersebut menyatu dalam satu wujud, yaitu wujud Yesus. Kepercayan Monophysit ini merupakan kepercayaan resmi bagi gereja, bahkan hingga dewasa ini. Lihat, T.J. De Boer, The History of Philosophy in Islam, 11-12; Ahmad Amin, Fajr al-Islam, 125; bandingkan 


\section{Diskursus Keillmuan: \\ Sejarah Transmisi Filsafat Hellenisme dalam Filsafat Islam}

sangat berjasa dalam menyebarkan filsafat dan ilmu pengetahuan Yunani, khusus dalam perannya sebagai penerjemah dari bahasa Yunani ke bahasa Syiria tersebar diberbagai negeri (kota) ke arah Timur hingga Persia. ${ }^{67}$ Akan tetapi, hingga abad keenam Masehi kota Iskandaria tetap menjadi marcusuar filsafat dan ilmu pengetahuan. ${ }^{68}$

Penyebaran warisan dari Yunani kuna hingga keberbagai negeri (kota) disebabkan beberapa faktor. Pertama, selama abad pertama kelahirannya, agama Kristen mendapat perlakuan yang tidak baik dan adil serta tidak diterima oleh penguasa kekaisaran Romawi. Bahkan hingga tiga abad kelahirannya, agama Kristen terlibat dalam perseteruan dengan filsafat Yunani (dengan filosuf pagan) dan kota Iskandaria menjadi pentas pertarungan itu. ${ }^{69}$ Karenanya, secara umum banyak umat Kristen yang meninggalkan kota Iskandaria; dan secara khusus umat Kristen aliran Nestorian juga dikejar-kejar karena pendirian keimanan mereka yang berbeda dengan paham resmi yang dianut oleh gereja dan negara. Di samping itu, juga disebab oleh penganiayaan tentara Kristen Byzantium yang menaklukan Iskandaria, sehingga mereka memindahkan sekolah-sekolahnya dari Iskandaria ke Antioka dan kemudian ke Harran (sebelah selatan Endessa dan dekat Nisbis). ${ }^{70}$

Kedua, faktor lain yang menyebabkan penyebaran filsafat dan ilmu pengetahuan keberbagai negeri (kota), yaitu karena sikap benci kaisar Romawi terhadap warisan dari Yunani kuno tersebut. Puncak dari sikap semacam itu, misalnya ketika kaisar Justianus (tahun 529), atas nama (pemahaman sempit) agama dan demi pertimbangan ekonomis, menutup musium Athena (pelanjut dari filsafat Athena) yang telah beroperasi selama satu mellenium. Kaisar yang tidak tahu menghargai arti penting ilmu itu, tidak saja menutup musium itu tetapi juga menghancurkan apa yang terdapat dalamnya. Sementara itu, ia juga menyatakan bahwa filosof dan ilmuan-ilmuan pagan tidak dibenarkan mengajar diperguruan-perguruan di Athena, yang sebelumnya gaji tenaga pengajar tersebut tidak pernah

dengan Mohd. Sulaiman Yasin, Pengantar Filsafat Islam (Kuala Lumpur: Dewan bahasa dan Pustaka, 1984), 229-230.

${ }^{66}$ Aliran ini tidak mengakui konsep "trinitas". Baginya Yesus adalah manusia yang juga sama dengan rasul-rasul terdahulu. Aliran ini menekankan kemanusiaan Yesus dan menyatakan bahwa Yesus hanya saluran untuk menyampaikan kekuatan Ilahi, Ruh Kudus kepada umat manusia. Mislanya, aliran ini juga menolak gelar-gelar Maria sebagai "Ibu dari Tuhan". Karena pendirian semacam itu aliran Nestorian menjadi bulan-bulanan bagi penguasa gerejani. Untuk menjaga keselamatanya mereka terpaksa hijrah kemana-mana. Lihat, T.J. Fe Boer, The History of Philosophy in Islam, 11-12; lihat juga, Charles Michael Stanton, Higher Learning in Islam the Classical Periode, A.D. 700-1300 (Rawman \& Littlefield Publishers, Inc., 1990), 54.

${ }^{67}$ Lihat, Seyyed Hossein Nasr, Science and Civilization in Islam, 30-31.

${ }^{68}$ Ahmad Fuad al-Ahwani, Filsafat Islam, 36.

${ }^{69}$ Ahmad Fuad al-Ahwani, Filsafat Islam, 38.

${ }^{70}$ Charles Michael Stanton, Higher Learning in Islam, 54-55. 
dibayarnya. ${ }^{71}$ Dan pada urutannya, para filosuf pagan tersebut diusir dari perguruan-perguruan di Athena. ${ }^{72}$ Akhirnya para filosuf berpindah ke Byzantium, kemudian ke Mesopotamia utara dan belakangan di Jundisapur. Di kota yang disebut belakangan ini para filosuf pagan bergabung dengan ilmuan-ilmuan Kristen Nestorian dan bersatu dalam alam intelektual bebas yang menghargai kajian-kajian terhadap filsafat dan sains tanpa halanganhalangan doktrinal. ${ }^{73}$

Sementara itu, sebelum kedatangan para filosuf dan ilmuan dari Athena, kota Jundisapur [didirikan oleh panglima Persia bernana Sabur ${ }^{74}$ ] sejak tahun 260 (abad ketiga) mulai menjadi pusat kajian fislafat dan ilmu (khususnya ilmu kedokteran) Yunani. Kondisi ini ditopang oleh banyaknya serjana-serjana (arsitektur dan kedokteran) yang turut menjadi tawanan perang. Kemudian lambat laun Jundisapur menjadi kota metropolis, pusat sains yang dipelajari dalam bahasa Yunani dan Sangsekerta dan kemudian dalam bahasa Syiria. Dalam kota Jundisapur didirikan perguruan-perguruan menurut model perguruan di Iskandaria dan Antioka. Dan di perguruan ini diajarkan ilmu kedoteran, metematika, astronomi dan logika. Kebanyakan teks pelajaran dari bahasa Yunani itu diterjemahkan dalam bahasa Syiria. Di samping itu, dimasukkan juga unsur-unsur sain dari India dan Persia sendiri. Perguruan-perguruan ini berlanjut sampai jauh setelah dinasti Abbasyiah berdiri; dan merupakan lembaga dan sumber penting filsafat dan ilmu pengetahuan dalam dunia Islam. ${ }^{75}$ Prihal hubungan antara kota Baghdad dan kota Jundisapur, Majid Fakhri menyatakan:

${ }^{71}$ Charles Michael Stanton, Higher Learning in Islam, 54-55.

${ }^{72}$ Ahmad Fuad al-Ahwani, Filsafat Islam, 39. Setelah agama Kristen mengalami kemenagan melawan paganisme, kemudian Kaisar Yustianus melarang pengajaran-pengajaran filsafat di Athena serta mengadakan tekan-tekanan terhadap filosuf-filosuf, sehingga banyak di antara mereka yang lari (diusir). 7 (Tujuh) orang (beraliran Neo-Platonisme) di antaranya lari ke Jundisapur (Persia) dan diterima dengan baik oleh Kaisar Anusyirwan, dimuliakan serta ditempatkan pada kedudukan terhormat; dan belakangan ada juga yang masuk agama Kristen. Di antara mereka masuk agama Kristen itu kemudian menulis buku tentang Neo-Platonisme dengan diberi corak kekristenan, seperti karya Deynesus, mengaku murid Paulus. Dalam bukunya ia menerangkan rahasia-rahasia ketuhanan dan tingkatan alam malaikat, dan pada akhirnya menjadi bagian dari ajaran dasar agama Kristen. Lihat, T.J. De Boer, The History of Philosophy in Islam, 14; Ahmad Amin, Fajr al-Islam, 129.

${ }^{73}$ Charles Michael Stanton, Higher Learning in Islam, 54-55.

${ }^{74}$ Panglima perang Persia yang bernama Sabur ini memimpin perang melawan serbuan tentara dari Romawi pada abad ketiga. Dalam pertempuran dahsyat tersebut tentara Persia di bawah pimpinan panglima Sabur mampu mengalahkan tentara Romawi dan mereka dijadikan tawanan. Untuk menampung tawanan perang tersebut Panglima Sabur kemudian memindahkan mereka ke sebuah tempat dekat Tustur, sebuah kota di Arabistan (Iran). Tempat itu kemudian dinamainya Jundisapur, artinya "pemusatan pasukan Sabur". Dan dalam tawanan tersebut banyak terdapat ilmuan dari beerbagai disiplin keilmuan yang belakangan mengembangkan kota Jundiasapur sebagai pusat ilmu. Ahmad Fuad al-Ahwani, Filsafat Islam, 39.

\footnotetext{
${ }^{75}$ Seyyed Hossein Nasr, Science and Civilization in Islam, 31.
} 
Kala itu, perguruan Jundisapur dengan fakultas kedokteran, akademi dan observatoriumnya mencapai puncak ketenarannya dan tetap berkembang dengan subur di saat kota Baghdad didirikan oleh khalifah Abbasyiah pada tahun 727. Mengingat Jundispur berdekatan dengan kota Baghdad maka hubungan secara politis dengan khalifah Abbasyiah sangat dekat. Akibatnya, dari perguruan inilah perkembangan ilmiah dan intelektual merambah ke seluruh kekuasaan Muslim. Sejak dini dalam pemerintahan Islam, Jundisapur telah menyumbang kepada khalifah di Baghdad sejumlah dokter-dokter istana, misalnya sejumlah Nestorian, seperti keluarga Bakhtisyu' yang masyhur, mengabdi kepada khalifah dengan setia selama lebih dua abad. ${ }^{76}$

Perlu dipertegas bahwa dalam "pengembaraan" filsafat dan ilmu pengetahuan Yunani kuna dari Iskandaria hingga ke Jundisapur, peranan serjana-sejarna Kristen (khususnya orang-orang Nestorian) dan peran orangorang Syiria (beserta bahasanya) sangat signifikan. Mereka telah berperan sebagai "hamz\}ah was\}al" (penghubung) ${ }^{77}$ bagi transmisi dan peralihan filsafat Yunani kuna ke filsafat Islam. Ini penting, karena agaknya, tanpa peran orang Kristen dan Syiria itu hampir dapat dipastikan bahwa sarjana Islam akan banyak kehilangan warisan dari Yunani. Upaya penerjemahan dilakukan sarjana Kristen dan orang-orang Syiria dari bahasa Yunani ke bahasa Syiria pada masa itu, kelak, sangat mempermudah penerjemahan dilakukan pada masa pemerintahan Islam. ${ }^{88}$

\section{E. Wacana Keilmuan: Hellenisasi Islam Era Penerjemahan}

Arus utama pemikiran Yunani/ Hellenisme masuk ke dunia Islam bukannya melalui manuskrip dan sumber-sumber asli dari Yunani, tetapi masuknya pemikiran tersebut melalui hasil terjemahan dilakukan oleh ilmuan dan serjana Kristen, Yahudi, Persia ke dalam bahasa Syiria. ${ }^{79}$ Akan tetapi, untuk keperluan penerjemahan ke dunia Islam pada periode-periode berikutnya tidak terlalu berarti kalau pemerintahan Islam, yaitu Dinasti Umayyah, tidak mengganti bahasa Persia, Yunani dan Syiria dengan bahasa Arab sebagai bahasa resmi negara menjelang akhir abad ketujuh. ${ }^{80}$ Dengan

\footnotetext{
${ }^{76}$ Majid Fakhri, A History of Islamic Philosophy, 15.

${ }^{77}$ Figur-figur era ini tetap saja berperan "hanya" sebagai "hamza washal" lantaran mereka semata-mata berperan sebagai penerjemah, hanya sedikit sekali diantara mereka yang melakuan pembaharuan-pembaharuan terhadap pemikiran Yunani tersebut. Kalaupun pembaharuan dilakukan, hanya pada masalah-masalah yang tidak sesuai dengan sistem keimanan mereka (khususnya ajaran Kristen), sehingga ia berusaha untuk mengalihkan Plato, misalnya, menjadi seorang pendeta Timur. Lihat, Ahmad Amin, Fajr al-Islam, 173.

${ }^{78}$ Ahmad Amin, Fajr al-Islam, 173.

${ }^{79}$ Charles Michael Stanton, Higher Learning in Islam, 63

${ }^{80}$ Majid Fakhri, A History of Islamic Philosophy, 17.
} 
kebijakan ini, penerjemaham dan pengembangan ilmu dan filsafat di dunia Islam menjadi lebih semarak, dan kelak mencapai puncak keemasannya. ${ }^{81}$

Meskipun pergantian bahasa itu awalnya lebih dimaksudkan untuk kepentingan politik dan administratif, ${ }^{82}$ tetapi tidak ayal lagi sangat besar pengaruhnya bagi perkembangan dan kesemarakan upaya-upaya penerjemahan warisan Yunani baik langsung (dari bahasa Yunani) ataupun tidak langsung (lewat bahasa Syiria) ke dalam bahasa Arab kelak. Tanpa kebijaksanaan menjadikan bahasa Arab sebagai bahasa resmi, sepertinya sulit untuk mengharapkan penerjemahan dalam bahasa Arab yang "melimpah" sebagaimana terjadi pada masa Dinasti Abbasyiah, dan persisinya pada era pemerintahan khalifah al-Ma'mun. Sekiranya bahasa Arab tidak dijadikan sebagai bahasa "tunggal", dan penerjemahan itu tidak "terkonsentrasi" ke dalam bahasa Arab, maka besar kemungkinan sarjanasarjana dan ahli penerjemah dengan latar belakang beragam (bahasa dab agama), akan menerjemahkan warisan Yunani tersebut mungkin tidak dalam bahasa Arab, tetapi dalam bahasa lain sesuai dengan kecenderungan meraka masing-masing. Belakangan, dengan kebijakan ini, menurut George Sarton, bahasa Arab benar-banar memainkan peran yang sangat penting dan utama, sehingga menjadi bahasa ilmu pengetahuan internasional, sebagaimana dikutip Mehdi Nekosteen: "Bahasa Arab merupakan bahasa sains internasional, sedemikian hebatnya sehingga tidak akan dapati ditandingi oleh bahasa lain kecuali bahasa Yunani, dan itu pun tidak akan pernah dapat terulang sampai kapan pun. Bahasa Arab bukan merupakan bahasa satu

\footnotetext{
${ }^{81}$ Upaya Dinasti Umayyah untuk menjadikan bahasa Arab sebagai bahasa resmi negera, dan pada gilirannya menjadi bahasa ilmu pengetahuan dalam penerjemahan, sekiranya 'Ali bin Abi T\{alib yang, kira-kira 20 tahun sepeninggalan Rasul Allah, tidak menganjurkan agar umat Islam mempelajari sastra arab pada umumnya, dan memerinthkan para ahli bahasa yang telah meletakkan kaidah-kaidah bahasa Arab pada khususnya. Ali bin Abi T\{alib bahwa masyarakat memerlukan ilmu tersebut karena bermamfaat dalam mengelaborasi pengetahuan dan pemahaman agama mereka. Walaupun pada masa khalifah Ali bin Abi T\{alib disebukan dengan sejumlah peperangan, tetapi tidak menjadikan aral bagi mereka untuk mendalami bahasa dan ilmu pengetahuan. Pada gilirannya, pada masa pemeritahan Bani Umayyah sejumlah khalifahnya memuliakan kedudukan ilmu-ilmu sastra, meninggikan kedudukan para penyair dan ahli-ahli agama. Dengan demikian, pada akhir kekuasaan bani Umayyah bermuculanlah sejumlah ilmu-ilmu rasional. Dari ilmu-ilmu rasional tersebut dimulailah upaya penerjemahan pada akhir abad pertama. Lihat, Syaikh Muhammad Abduh, Islam Ilmu Pengetahauan, dan Masyarakat Madani (Jakarta: PT. RajaGrafindo Persada, 2005), 143-144.

${ }^{82}$ Pergantian berbagai bahasa dengan bahasa Arab sebagai bahasa resmi negara menandai usaha pertama pemerintahan Islam untuk menunjukkan keunggulan literer mereka, sebagaimana halnya keunggulan militer dan politik mereka atas bangsa-bangsa yang ditaklukan selama ini. Sulit untuk dipastikan apa motivasi dan latar belakang pergantian bahasa tersebut, tetapi ada keterangan (dan inipun hanya disinyalir) bahwa pergantian bahasa asing ke dalam bahasa Arab apakah disebabkan oleh rasa iri atau bukan umat Islam terhadap monopoli yang dipertahankan orang-orang non-Islam (terutama umat Kristen dan Yahudi) sebagai pegawai-pegawai khalifah. Tetapi yang pasti dari segi pertimbangan praktis pun pergantian itu merupakan suatu keniscayaan. Majid Fakhri, A History of Islamic Philosophy, 17.
} 
kaum, satu bangsa, tetapi merupakan bahasa dari beberapa aum, bangsa dan agama." 83

Pada periode awal, masa dinasti Umayyah, kegiatan penerjemahan dilakukan dengan pertimbangan-pertimbangan praktis dan kecenderungankecenderungan pragmatis. Misalnya, pada masa ini penerjemahan hanya dilakukan pada bidang tertentu, yaitu bidang kedokteran dan astrologi (astronomi). Dan kedua bidang ini memang mempunyai nilai praktis (untuk keperluan sehari-hari) dan nilai prgamatis (untuk tujuan-tujuan tertentu) dalam hidup ini. Sementara warisan pemikiran Yunani bersifat abstrak dan filosofis $^{84}$ baru dilakukan pada berkembangan dekade berikutnya. Kecenderungan praktis dan pragmatis itu pada tahap dini dapat dilihat pada pribadi Khalid bin Yasid --putra (kedua) mahkota Umayyah urung menjadi khalifah dan beralih menekuni ilmu-- memerintahkan penerjemahan karya dalam bidang kedokteran, astrologi dan kimia. ${ }^{85}$

Setelah penaklukan Demaskus dan pembangunnya sebagai ibu kota propinsi Syiria (dan kemudian menjadi ibukota pemeritahan Bani Umayyah) telah terjadi interaksi antara budaya Arab dengan Yunani yang ada di kota ini. Karenanya, selama abad ketujuh, pemerintahan Bani Umayyah mengandalkan komunitas ilmuan dan sarjana dari kota-kota tetangga, Nisbis, khususnya untuk mendapatkan dokter. Dokter-dokter beragama Kristen secara bergantian menjadi dokter di istana selama pemerintahan Bani Umayyah. Di samping sebagai dokter biasaya mereka juga berperan sebagai penasehat bagi penguasa. Sadar akan penting ilmu itu secara praktis dan pragmatis beberapa di antara anggota keluarga istana meminta kepada sarjana Kristen tersebut untuk menerjemahkan karya-kaya kedokteran dari bahasa Syiria ke dalam bahasa Arab. Kegiatan ini terjadi sejak tahun 638; dan sekaligus menandai awal penerjemahan warisan Yunani tentang karya-karya kedokteran. ${ }^{86}$ Begitu

\footnotetext{
${ }^{83}$ Mehdi Nakosteen, Konstribusi Islam atas Dunia Intelektual Barat, viii.

${ }^{84}$ Kendatipun bersentuhan dengan tradisi filsafat dan teologi Hellenisme, Bani Umayyah tetap tidak begitu berminat untuk mamajukan kajian filsafat dan teologi. Demi mempertahan kekuasaan, Bani Umayyah menyebarkan suatu doktrin simplistis yang memberi jastifikasi dan legalisasi bagi stabilatas dan kelanggengan kekuasaan Bani Umayyah untuk memerintah dengan hak dan kekuasaan --berdasarkan penafsira penguasa-- berasal dari Tuhan. Bani Umayyah sepertinya enggan untuk memperkenalkan sistem hukum agama yang akan mengurangi dan merongrong kekekuasaan mereka. Bani Umayyah juga tidak begitu tertarik untuk menafsirkan al-Qur'an dan al-Sunnah yang merumitkan bagi drinya, dan memandang hal itu sebagai kemungkinan ancaman bagi kekuasannya. Chales M. Stanton, Higher Learning in Islam, 64.

${ }^{85}$ Majid Fakhri, A History of Islamic Philosophy, 17.

${ }^{86}$ Seperti disebutkan di atas kecenderungan awal begitu kuat untuk menerjemahan karya-karya kedokteran demi pertimbang praktis dan pragmatis. Ini dapat dipahami bahwa kedokteran berkaitan dengan sehat-kehidupan dan sakit-kematian. Seorang penguasa, apalagi untuk terus dapat bertahan di kursi/ tampuk kekuasaannya, maka yang paling ditakuti adalah "sakit" dan untuk tetap sehat diperlukan dokter yang terus dapat mengontrol bagaimana kesehatan sang penguasa (tanpa bermaksud menafikan kekuasaan/ kehendak Tuhan tentang ajal seseorang).
} 
juga dalam bidang astrologi (astronomi) ${ }^{87}$ penerjemahan dilakukan lantaran adanya doktrin dari agama-agama Timur yang menganggap bintang-bintang sebagai alat untuk mengurai alam suprnatural; dan gerakan bintang-bintang tersebut dapat digunakan untuk menafsirkan bagaimana kehendak Tuhan. Karenanya, timbul hasrat kuat untuk mengetahui astrologi ("posisi dan gerak bintang") sekaligus mendorong usaha penerjemahan bidang astrologi tersebut pada pemerintahan Bani Umayyah. ${ }^{8}$

Namun, kecenderungan praktis dan pragamtis ini bukanlah sematamata monopoli pemerintahan Bani Umayyah, tetapi --seiring kecendrungan universal untuk tetap mempertahan kekuasaan-- ini juga berlaku pada pemerintahan Dinasti Abbasiyah. Bahkan kecenderungan pada astrologi yang, sepertinya "irrasional", mempercayai gerak-gerak dan posisi bintang juga diyakin oleh oleh Khalifah al-Ma'mun yang terkenal rasional, sebagiamana penuturan Majid Fakhri:

Pergolakan politik yang menyebabkan jatuhnya Bani Umayyah dan naiknya Dinasti Abbasyiah sebagai penggantinya menyakinkan di kalangan Dinasti Abbasyiah bahwa rahasia nasib manusia dan jatuhbangunnya kerajaan berlaku dengan pasti menurut perhintungan bintang, dan hanya orang-orang bijaklah yang mempu memahaminya. Dari sinilah bermula muncul hasrat yang kuat untuk memahami dan menerjemahkan karya-karya kuna berkenaan dengan astrologi. Bahkan khalifah-khalifah yang sangat rasional sekalipun, seperti al-Ma'mun tidak luput dari ketergantungan pada perhitungan bintang-bintang tersebut. Ia tidak saja mengangkat seorang astrolog sebagai pembantunya, tetapi ia juga tidak dapat melakukan gerakan militer dan kebijakan politik yang penting tanpa terlebih dahulu berkonsultasi dengan astrolog tersebut. ${ }^{89}$

Pada masa Bani Umayyah penerjemahan masih bersifat pribadiindividual dan/atau bukan/ belum merupakan sebuah gerakan. Belakangan, baru pada era pemerintahan Dinasti Abbasyiah, khususnya periode-periode awal, dan terlebih-lebih pada masa pemerintahan al-Ma'mun penerjemahan sudah bersifat kolektif-komunal dan merupakan sebuah gerakan yang terpadu dan sistematis serta langsung di bawah patronase penguasa.

\footnotetext{
${ }^{87}$ Ada yang menyebutkan bahwa terdapat perbedaan signifikan antara astrologi dan astronomi sebagai sebuah disiplin keilmuan. Kalau yang disebut pertama cenderung mengandung unsur-unsur ramalan dan sepintas tidak mencerminkan dan sulit dipertanggungjawabkan sebagai sebuah disiplin keilmuan-ilmiah. Sehingga astrologi lebih banyak dipergunakan pada awal-awal perkembangan ilmu pengetahuan dalam Islam. Sebaliknya, terrm keilmuan yang disebutkan belakangan, merupakan disiplin ilmu yang relatif "bersih" dari unsur ramalan dan/ mitos-mitos serta dengan sendirinya lebih dapat dipertanggungjawabkan dari segi keilmiahnnya. Sehingga dewasa ini kita lebih sering menggunakan term astronomi tinimbang kata astrologi.

${ }^{88}$ Charles M. Santon, Higher Learning in Islam, 64.

${ }^{89}$ Majid Fakhri, A History of Islamic Philosophy, 8.
} 
Karenanya, jumlah hasil terjemahan masa Bani Umayyah tidak lebih sebuah proyek kecil; sebaliknya merupakan suatu proyek besar-besaran pada masa pemerintahan khalifah-khalifah pertama Dinasti Abbasyiah. ${ }^{90}$

Di bawah perlindungan para khalifah Dinasti Abbaysiah, khususnya pada masa pemerintahan al-Mansur, al-Rasyid dan al-Ma'mun, puncak aktifitas penerjemahan berlangsung sekitar 100 tahun antara tahun 750 hingga 850. Dan dalam penerjemahan itu bukan saja karya-karya orang Kristen Nestorian dan pagan dari Mesopotamia yang tersedia secara melimpah, tetapi juga lewat penaklukan di daerah-daerah perbatasan Byzantium, manuskrip-manuskrip tambahan adalah merupakan bagian dari kekayaan dibawa pulang ke Baghdad. Didorong oleh hasrat begitu kuat untuk mempelajari warisan pengetahuan dari Yunani, para khalifah disebut sebelumnya, bila tidak memperolah naskah-naskah dengan cara penaklukan, maka mereka membelinya dari musuh mereka, khusunya naskah-naskah dari Byzantium di Konstantinopel. ${ }^{91}$

Khalifah al-Manshur yang membangun kota Baghdad --pada saatnya nanti menjadi mercusuar di Timur dan jantung dunia Islam dalam kurun waktu lama-- disebut-sebut bahwa pada masa pemerintahannya mendatangkan seorang serjana dari Jundisapur, Jurjis bin Bakhtaisyu' ${ }^{92}$ untuk diangkat menjadi kepala tim dokter istana, hingga wafanya al-Mansur. ${ }^{93}$ Akan tetapi, setelah lanjut usia Jurjis kembali lagi ke Jundispaur dan kedudukanya digantikan oleh keturunanya, Gabrel Bakhtyshu' yang bekerja

${ }^{90}$ Chales M. Santon, Higher Learning in Islam, 65.

${ }^{91}$ Chales M. Santon, Higher Learning in Islam, 65 .

${ }^{92}$ Keterangan lain menyebutkan bahwa ketika al-Manshur bertahun-tahun menderita sakit, ia meminta bantuan pada dokter Jundisapur. Selama beberapa waktu, pusat medis dan rumah sakit di Kota Jundispur dikepalai oleh Jurjis Bakhtyisu' [nama Syiriahnya berarti "yang menyelamatakan"], dokter terkenal pertama dari sebuah keluarga yang kelak menjadi keluarga medis paling penting dalam dunia Muslim, dan anggota keluarganya terusmenerus menjadi dokter terkemuka hingga akhir abad ke-ll M). Reputasi Jurjis Bukhtyshu' sebagai dokter sangat mumpuni terdengar oleh khalifah dan meminta agar dokter Kristen terkenal itu dijemput untuk datang ke istananya. Keberhasilan menyembuhkan penyakit khalifah merupakan awal proses yang pada akhirnya mengalihkan pusat medis dari Jundisapur ke Baghdad. Namun di akhir usianya ia kembali ke Jundisapur, lalu meninggal dunia di kota asal nenek moyangnya. Tetapi para mahasiswa, juga termasuk keturunannya melawat kembali ke Baghdad, telah membuat jaringan organik antara perguruan ini dengan pusat medis pertama di Baghdad. Lihat, Seyyed Hossen Nasr, Nasr, Science and Civilization in Islam, 193; Ahmad Fuad alAhwani, Filsafat Islam, 43; Philip K. Hitti, History of the Arab, 309

${ }^{93}$ Seyyed Hossesn Nasr, Science and Civilization in Islam, 193; Frans Rosenthal, The Classical Heritage in Islam (London: Routledge \& Regan Paul, 1975), 6. Kesan umum yang dapat diperoleh mengenai al-Manshur bahwa ia berminat sekali pada karya-karya ilmiah dan filosofis serta memberikan dukungan dan perlindungan pada kegiatan para penerjemah. Meskipun demikian, berhubungan dengan langkanya para ahli dan sarjana serta karena masih kurangnya bahan-bahan ilmiah dan filasfat Yunani yang dapat diperolah, sehingga proses penerjemahan pada masanya tidak mendapat kemajuan sesuai harapannya. Majid Fakhri, A History of Islamic Philosophy, 19. 
pada khalifah al-Mahdi, di samping juga berkerja di istana wazir Ja'far alBarmaki dan bahkan hingga masa al-Makmun nantinya. ${ }^{94}$

Sementara penerjemahan sedang berlangsung, di sadari oleh para sarjana dan ahli penerjemah itu bahwa sedemikian besar dan kayanya warisan filsafat dan ilmu pengetahuan Yunani yang harus diupayakan penerjemahannya. Maka di antara mereka mengusulkan kepada khalifah alMa'mun untuk mengorganisir aktifitas penerjemahan dalam skala lebih luas dan intensif. ${ }^{95}$ Kemudian dalam kebijakannya, al-Ma'mun mendirikan Bayt alHikmah ("Gedung Hikmah"), sebuah tempat kombinasi penerjemahan, akademi dan perpustakaan. Bayt Hikmah merupakan lembaga pendidikan yang terpenting artinya setelah Musium Iskandaria didirikan pada pertengahan pertama abad ke-3 SM. ${ }^{96}$

Untuk menyediakan dan melengkapi kepustakaan Bayt al-Hikmah yang baru didirikan itu dengan karya-karya ilmiah dan filsafat, al-Makmun mengirim utusan ke Byzintium untuk mencari dan memperoleh buku-buku "pelajaran kuno" dan kemudian diserahkan kepada sekelompok sarjana untuk diterjemahkan. Termasuk dalam kelompok ini terdapat sejumlah nama sangat terkenal, seperti Yahya bin Musawayh (guru Hunain ibn Ishak) --sebelumnya juga mengabdi kepada khalifah al-Mansur dan Harun-- diangkat al-Ma'mun sebagai Direktur Bayt al-Hikmah segera setelah didirikannya. Bersama dengan beberapa penerjemah terkenal lainnya, seperti al-Hajjaj bin Muthar, Yahya bin Bithriq dan Salm, sekaligus disebut-sebut sebagai pengurus Bayt alHikmah. $^{97}$

Namun dari sekian banyak penerjemah pada masa itu yang paling terbesar dan berjasa adalah Hunain Ibn Ishak (Johannitus Onan, sebagaimana ia dikenal di Barat pada abad pertengahan). Hunain bukan saja sebagai seorang penerjemahan yang pandai dan lihai, tetapi ia juga salah seorang di antara dokter-dokter masyhur pada zamanya. Lebih jauh, bagaimana peran tokoh ini alam proses aktivitas penerjemahan, Nasr memaparkan:

Dibantu oleh kemanakannya, Hubaisy dan anaknya Ishak, Hunain sering menerjemahkan teks dari bahasa Yunani ke dalam bahasa Syiria dan

\footnotetext{
${ }^{94}$ Phillip K. Hitti, History of the Arab, 309; lihat juga, Ahmad Fuad al-Ahwani, Filsafat Islam, 43.

${ }^{95} \mathrm{~W}$. Montgemory Watt, Islamic Philosophy and Theology (Chicago: Edinburgh University Press, 1962), 41.

${ }^{96}$ Lihat, Phillip K. Hitti, History of the Arab, 310.

${ }^{97}$ Majid Fakhri, A History of Islamic Philosophy, 24. Pada saat itu Bayt al-H\}ikmah selain sebagai pusat penerjemahan juga dipergunakan sebagai tempat untuk mempelajari sekaligus menyebarkan teologi (Mua'tazilah\} dan filsafat. Pimpinan lembaga ini, misalnya, mengundang sejumlah ilmuan dan sarjana dari berbagai daerah untuk berdabat dan berdiskusi di anatara mereka dalam semua lapangan ilmu pengetahuan, khususnya menyangkut tentang agama, teologi dan filsafat serta ilmu-ilmu kealaman. Lihat, Charles M. Santnton, Highere Learning in Islam, 75 .
} 
menyerahkan penerjemahan dari bahasa Syiriah ke bahasa Arab yang dilakukan oleh mahasiswa dan khususnya Hubaisy. Pada waktu itu, ini ia memeriksa terjemahan akhir dan membandingkannya dengan teks Yunani aslinya. Kadang-kadang ia menerjemahkan langsung dari bahasa Yunani ke dalam bahasa Arab. Dengan cara begini, Hunain dan perguruannya membuat banyak terjemahan bagus, termasuk 95 karya Galen ke bahasa Syiriah dan 99 buah ke bahasa Arab. Masih ada penerjemah masyhur lainnya .... Tetapi tidak seorangpun dari tokohtokoh tersebut yang dapat menandingi Hunain, keahliannya sebagai penerjemah dan juga sekaligus sebagai dokter, membuatnya pantas dipandang sebagai seorang di antara tokoh-tokoh utama sejarah medis Islam. $^{98}$

Dalam pandangan para ilmuan berbahasa Arab menyebutkan bahwa terjemahan dilakukan pada masa-masa awal dari segi gramatika terkadang janggal dan sulit dimengerti. Karenanya, Hunain dan timnya berupaya untuk menerjemahkan ulang. ${ }^{99}$ Sebagian hasil terjemahan masa awal banyak bersifat harfiah dan tidak akurat. Untuk itu, perlu direvisi guna menangkap makna lebih tepat dan akurat. Akan tetapi biasanya terjemahan semacam ini terjadi pada karya terjemahan dari versi bahasa Syiria, dan bukan pada karya terjemahan langsung dari bahasa asilnya, Yunani. ${ }^{100}$

Penerjemahan dilakukan oleh Hunain Ibn Ishak beserta timnya menandai tahap penerjemahan yang sangat menentukan. Begitu pula timbulnya perhatian baru dalam tingkat kecermatan dan keseksamaan yang baik, mengharuskan untuk menerjemahkan kembali naskah-naskah ilmiah dan filsafat. ${ }^{101}$ Untuk kepiawaian dan keahlian itu Hunain Ibn Ishak digaji sebesar 500 dirham perbulan; dan al-Ma'mun juga membayarnya dalam bentuk emas seberat buku ia diterjemahkan. ${ }^{102}$

\footnotetext{
${ }^{98}$ Seyyed Hossein Nasr, Science and Civilization in Islam, 195.

${ }^{99}$ Michael M. Stanton, Higher Learning in Islam, 66-67.

${ }^{100}$ Lihat, Watt, Islamic Philosophy and Theology, 82.

${ }^{101}$ Majid Fakhri, A History of Islamic Philosophy, 25.

${ }^{102}$ Phillip K. Hitti, History of the Arab, 113.
} 
Demikian berkembangnya penerjemahan pada era ini, sehingga jumlah karya-karya Yunani hasil terjemahan dalam bahasa Arab begitu luar biasa, sangat melimpah. Pada akhir abad kesembilan belas hampir semua karya yang diketahui dari musium-musium Hellenistik telah tersedia bagi ilmuan-ilmuan Muslim. Dari kondisi seperti ini, kota Baghdad benar-benar mejadi mercusuar ilmu pengatahun dan pusat peradaban anak manusia selama berabad-abad lamanya. Dari situasi kondusif seperti itulah pada tahun-tahun berikutnya dunia Islam melahirkan sedemikian banyak filosuf dan ilmuan diseluruh bidang keilmuan. Dunia Islam telah berhasil melahirkan "karya" mencengangkan Dunia Barat yang pada waktu itu baru belajar mengeja namanya.

\section{F. Penutup}

Sebagaian orang mengklaim bahwa filsafat dan ilmu pengetahuan dalam Islam tidaklah "pure" lantaran diambil dan dipengaruhi oleh pemikiran Hellenistik. Kalau begitu logikanya, maka tidak ada yang "pure" di muka bumi ini. Karena siapakah tidak mengambil pelajaran dari orang sebelumnya dan sekaligus tidak terkena pengaruh dari para pendahulunya. Memang tidak dapat dipungkiri bahwa adalah benar: (i) pemikiran filsafat dan ilmu dalam Islam dipengaruhi oleh pemikiran Hellenisme; dan (ii) pemikiran filosuf dan ilmuan Muslim banyak "berguru" (tidak langsung) pada filasuf Yunani kuno, khususnya Aristoteles dan Plato. Akan tetapi, menurut Ibrahim Madkour, adalah salah jika ada pendapat bahwa: (i) belajar (berguru) itu adalah semata-mata meniru dan mengikuti tanpa reserve serta membebak begitu saja; (ii) filsafat Islam tidak lebih merupakan pemikiran yang diadopsi dari Aristoteles, seperti disangkakan Renan; atau dari Neo-Platonisme, seperti dituduhkan Rehem. ${ }^{103}$ Pada dasarnya, kata Rahman, tidak ada yang baru dikenakan pada sistem pemikiran Yunani dipergunakan oleh para filosuf Muslim; bahan-bahannya adalah hasil dari Hellenisme akhir, tetapi filosuf Muslim memberi arah baru, hingga muncul pola baru pula, dan situlah letak orisinalitasnya. ${ }^{104}$

Sesungguhnya pemikiran dan peradaban anak manusia merupakan suatu kontinuitas, sehingga bangsa/golongan tidak mungkin terelakkan dari kesinambungan tersebut. Kalau itu dingkari maka kita menjadi a historis. Karenannya, tepat sekali untuk menyimak kata al-Kindi, hasil elaborasi terhadap hadis Nabi saw. ia mengatakan: "Kita tidak perlu malu mengakui kebenaran dan mengambilnya dari sumber manapun datangnya; kalaupun kebenaran tersebut dibawa kepada kita oleh generasi-generasi terdahulu dan bangsa-bangsa asing. Sebab bagi orang pencari kebenaran, tak ada nilai yang lebih tinggi daripada kebenaran itu sendiri; kebenaran tidak pernah

\footnotetext{
${ }^{103}$ Ibrahim Madkour, Fi al-Falsafah al-Isla>miyah: Manhasj wa Tat\}biquh, (Mesir: Da alMa'arif, 1976), 26

${ }^{104}$ Lihat, Falur Rahman, Islam, hal. 171
} 
merendahkan atau menghindar dari orang menerimanya, tetapi sebaliknya membuatnya jadi mulia. ${ }^{105}$

Wallahu'alam.

Ma> al-tawfi>qwa al-hidaryah illa bi Allah.

*Penulis adalah alumni Sl Aqidah-Filsafat, Ushuluddin IAIN Jakarta. Tenaga Pengajar UIN Suska Riau; kini sedang studi pada Program S3 Sekolah Pascasarjana UIN Syarif Hidayatullah, Jakarta.

\section{DAFTAR PUSTAKA}

Abduh, Muhmmad, Risalah al-Tauhid, Kairo: t.p., 1366

, Islam Ilmu Pengetahauan, dan Masyarakat Madani (Jakarta: PT. RajaGrafindo Persada, 2005).

Ahmad, Mumtaz, (ed.), State, Politics dan Islam, Indianapoilis: American Trusst Publications, 1986

al-Ahwani, Ahmad Fuad, Filsafat Islam, Jakarta: Pustaka Firdaus, 1995

Ali, Syed Ameer, The Spirit of Islam, Delhi: Idarah-iAdabiyaht-i Delhi, t.t.

Amin, Ahmad, Fajr al-Islam, (Kairo: Maktabah al-Nahdha al-Mishriyah, 1975

Atiyeh, N. George, Al-Kindi:Tokoh Filosuf Muslim, Bandung: Pustaka, 1983

Azra, Azyumardi, Pendidikan Islam Tradisi dan Modernisasi Menuju Melinium Baru, Jakarta: Logos, 1999

Bello, Iysa A., The Medieval Islamic Controversy Between Philosophy and Ortodexy: Ijma' dan Ta'wil in The Conflict Between al-Ghazali dan Ibn Rusyd, Leiden: E.J. Brill, 1989

De Boer, T.J., The History of Philosophy in Islam, New York: Dover Publications, Inc., 1967

Encyclopaedia Britanica, "Hellenic Age", Vol. 1l, Chicago: Willian Benton, 1970

Edwards, Paul, (ed.), The Encyclopedia pf Philosophy, Vol. $3 \& 4$, New York: Macmillan Publishing, 1972

Fakhri, Majid, A History of Islamic Philosophy, New York: Colombia, 1970

Goitein, S.D., Studies in Islam History and Institutions,(Leiden: E.J. Brill, 1968

Hitti, Philip K., History of the Arab, London: Macmillan Press, 1970

Hodgson, Marshall G.S., The Venture of Islam Conscience and History in a World Civilization, Chicago \& London: The University of Chicago Press, 196

${ }^{105}$ Charles Michael Stanton, Higher Learning in Islam, 81. 
Ibn Rusyd, Fasl al-Maqal fi ma Bayn al-Hikamh wa al-Syari'ah min al-Ittisal, Kairo: Dar al-Ma'arif, 1972

Ibn Tufayl, The History of Hayy bin Yaqzan, London: Draft Publisher Limited, 1998 Lane, Graig, William, The Kalam Cosmological Argument, New York: Banes \& Nobel, 1979

Louis Marlow, Masyarakat Egaliter Visi Islam, Bandung: Mizan, 1997

Luwis, Bernard, The Political Lenguage of Islam, Chicago: University of Chicago , Muslim Discovery of Europe, New York \& London: W.W. Norton \& Company, 1982

Madjid, Nurcholish, Islam Doktrin dan Peradaban, Jakarta: Paramadia, 1992 , Islam Agama Kemanusian, (Jakarta: Paramadina, 1995) , Kaki Langit Peradaba Islam, Jakarta: Paramadina, 1997 "Kata Pengantar" dalam Passing Over Melintasi Batas Agama, Jakarta: Gramedia, 1998 (ed.), , (ed.) Khazanah Intelektual Islam, Jakarta: Bulan Bintang, 1984 , Tradisi Islam, Jakarta: Paramadina, 1997

Madkour, Ibrahim, Fi al-Falsafah al-Islamiyah: Manhaj wa Tathbiquh, Mesir: Da alMa'arif, 1976

Mahdi Ghulsyani, Filsafat Sains menurut Al-Qur'an, Bandung: Mizan, 1988

Mahmud, Abdul Halim, Falsafah Ibn Tufayl wa Risalah Hayy Bin Yaqzan, Beirut: Makthbah al-Madrasah, 1972

Mulyadi Kartanegara, "Metodologi Kajian Filsafat Islam", dalam Refleksi, Jurnal Fakultas Ushuluddin, Vol. I, No. 1, 1998, hal. 4

Muthahhari, Mu rthada Keadilan Ilahi, Bandung: Mizan, 1992, hal. 19

Murata, Sociko, The Tao of Islam, Bandung: Mizan, 1996

Nakosteen, Mehdi, Konstribusi Islam atas Dunia Intelektual Barat Deskripsi Analisis Abad Keemasan Islam, Surabaya: Risalah Gusti, 2003

Naquib al-Attas, Konsep Pendidikan dalam Islam Bandung: Mizan, 1984

Nasr, Seyyed Hossein, Intelektual Muslim: Teologi, Filsfat dan Gnosis, Yogyakarta: Pustaka Pelajar, 1996 , Ideals and Realities of Islam, London: Unwin Paperback, 1979 "The Qur'an dan Hadith as Source and Inspiration of Islamic Philosophy", dalam Seyyed Hossein Nasr \& Oliver Leaman, History of Islamic Philosophy, London \& New York: Routledge, 1996, Vol. I

Science and Civilization in Islam, Cambrige: Harvard University Press, 1968

Nasution, Harun, Muhammad Abduh dan Teologi Rasionalitas Mu'tazilah, Jakarta: UI-Press, 1987 , Akal dan Wahyu Dalam Islam, Jakarta: UI-Press, 1986 , Filsafat dan Mistisisme Dalam Islam, Jakarta: Bulan Binatang, 1992 

, Teologi Islam, Jakarta: UI-Press, 1986 , Islam Ditinjau dari Berabgai Aspeknya, Jakarta: UI-Press, 1978

Nazir, Muhammad, Sisi kalam Dalam Pemikiran Syekh Abdurrahman Siddik al-Banjari, Pekanbaru: SUSQA Press, 1992

Rahman, Fazlur, Gelombang Perubahan Dalam Islam Study Tentang Fundamentalisme Islam, Jakarta: PT. Raja Grafindo Persada, 2000 , Islam, Bandung: Pustaka, 1984

Rosenthal, Frans, The Classical Heeritage in Islam, London: Routledge, 1975

Sharif, M.M., Para Filosuf Muslim, Bandung: Mizan, 1994, hal. 47;

Sharif, M.M., "Philosophical Teacings of the Qur'an" dalam M.M. Sharif (ed.), A History of Muslim Philosophy, Delhi: Low Price Publications, 1961, Vol. I, Saunders, J.J., A History of Medieval Islam, London: Reutledge Kesen Paul, 1965

Turner, Howard T. , Science in Medieval Islam, Austin: University of Texas Press, 1961

Shiniogaki, Kazou, Kiri Islam: Antara Modernisme dan Postmodernisme, Telaah Kritis Pemikiran Hasan Hanafi, Yokyakarta: LKIS, 1993

Stanton, Charles Michael, Higher Learning in Islam: The Classical Period 700-1300, Rewman \& Littlefield Publishers, Ins, 1990

al-Syarastani, al-Mihal wa al-Nihal, Cairo: t.p., 1951

Wan Mohd Nor Wan Daud, Filsafat dan Praktik Pendidikan Islam Syed M. Naquib Al-Attas, (Bandung: Mizan, 2003)

W. Montgemory Watt, Islamic Philosophy and Theology, Chicago: Edinburgh University Press, 1962

Yasin, Muhd. Sulaiman, Pengantar Filsfat Islam, Kuala Lumpur: Dewan Bahasa dan Pustaka, 1984

Zahra, Muhammad Abu, Aliran Politik dan Aqidah dalam Islam, Jakarta: Logos Publishing Hoese, 1996

Harun, I. (2015). EFEKTIFITAS PENGGUNAAN TEKNOLOGI INFORMASI DAN

KOMUNIKASI DALAM PEMBELAJARAN PENDIDIKAN AGAMA ISLAM.

POTENSIA: Jurnal Kependidikan Islam, 1(2), 175-190. 
30 Diskursus Keilmuan:

Sejarah Transmisi Filsafat Hellenisme dalam Filsafat Islam 